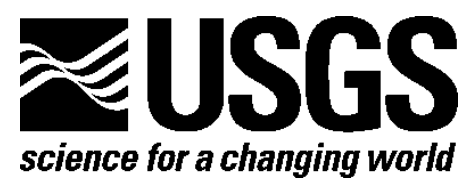

Prepared in Cooperation with the National Park Service

\title{
USGS-NPS Servicewide Benthic Mapping Program (SBMP) Workshop Report
}

By Christopher S. Moses, Amar Nayegandhi, John Brock, and Rebecca Beavers

Open-File Report 2010-1194

U.S. Department of the Interior

U.S. Geological Survey 


\section{U.S. Department of the Interior \\ KEN SALAZAR, Secretary}

\section{U.S. Geological Survey \\ Marcia K. McNutt, Director}

U.S. Geological Survey, Reston, Virginia 2010

For product and ordering information:

World Wide Web: http://www.usgs.gov/pubprod

Telephone: 1-888-ASK-USGS

For more information on the USGS - the Federal source for science about the Earth,

its natural and living resources, natural hazards, and the environment:

World Wide Web: http://www.usgs.gov

Telephone: 1-888-ASK-USGS

This report summarizes discussion at the USGS-NPS Servicewide Benthic Mapping Program Workshop June 3-5, 2008. This event was co-sponsored by the U.S. Geological Survey (USGS), and the National Park Service. Comments made by speakers not affiliated with the USGS do not necessarily reflect the positions of the USGS.

Suggested citation:

Moses, C.S., Nayegandhi, Amar, Brock, John, and Beavers, Rebecca, 2010, USGS-NPS Servicewide Benthic Mapping Program (SBMP) workshop report: U.S. Geological Survey Open-File Report 2010$1194,32 \mathrm{p}$.

Any use of trade, product, or firm names is for descriptive purposes only and does not imply endorsement by the U.S. Government.

Although this report is in the public domain, permission must be secured from the individual copyright owners to reproduce any copyrighted material contained within this report. 


\section{Contents}

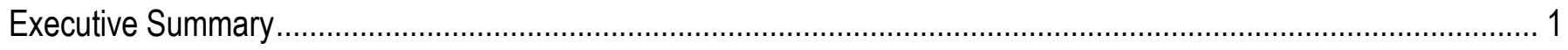

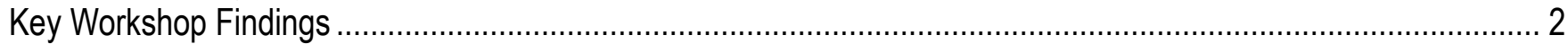

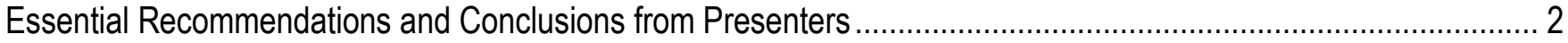

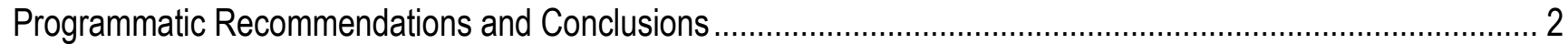

Regional Recommendations and Conclusions ......................................................................................... 2

Recommendations and Conclusions from Mapping Programs ................................................................... 3

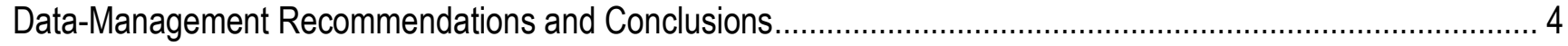

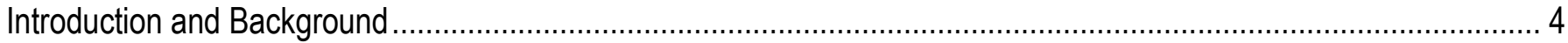

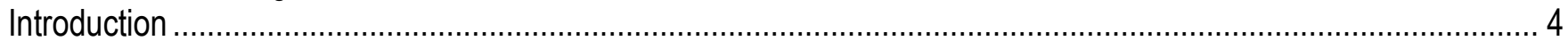

Need for a Specialized Servicewide Benthic Mapping Program ………......................................................... 5

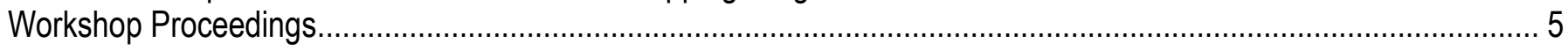

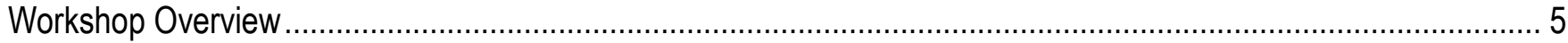

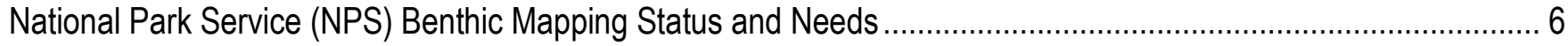

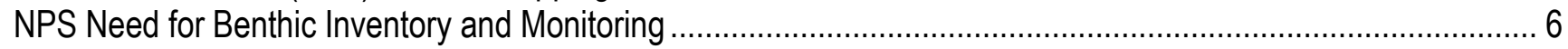

Overview of Benthic Inventory and Monitoring in NPS Units .................................................................... 7

Northeast Region (NER) ........................................................................................................

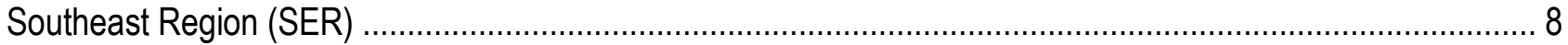

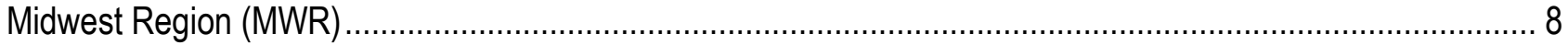

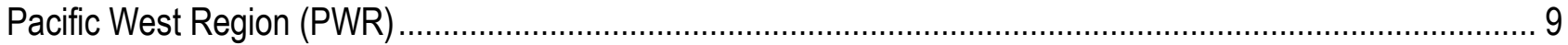

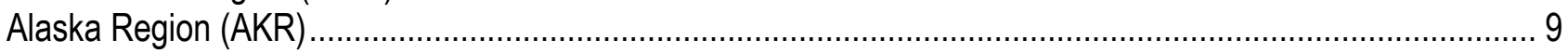

Prior and Existing NPS Mapping Programs ………............................................................................

NPS Vegetation Inventory and Mapping Program..................................................................................

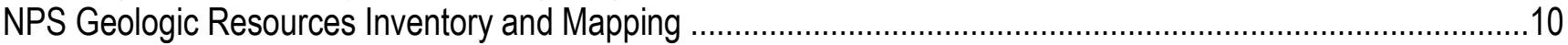

NPS Submerged Resources Program.................................................................................................

Other Agency Mapping Programs, Classification Schemes, and Geospatial Data Networks ..................................11

NOAA National Marine Sanctuaries Mapping Program ..............................................................................11

NOAA Tropical Marine Mapping Program …………….....................................................................

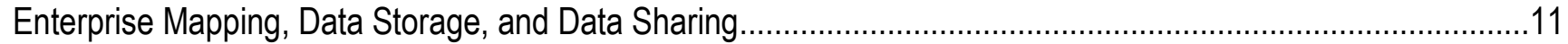

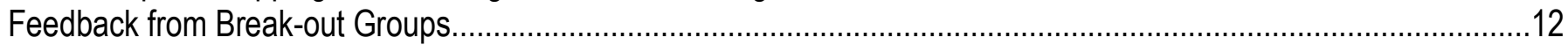

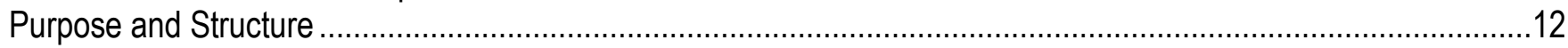

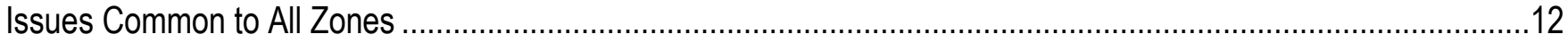

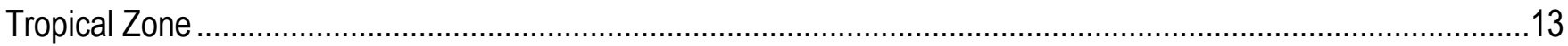

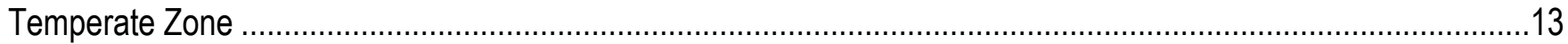

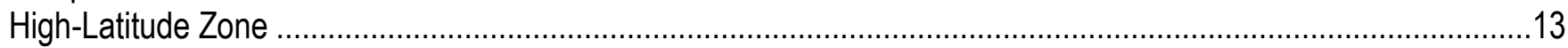

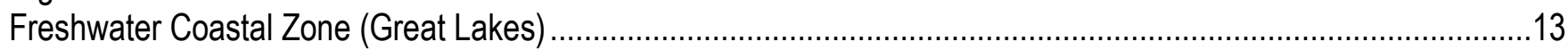

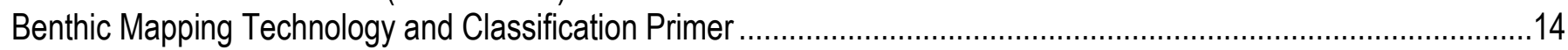

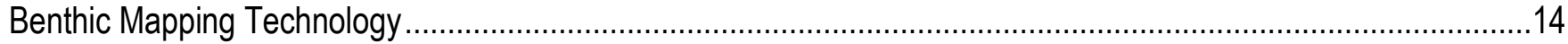

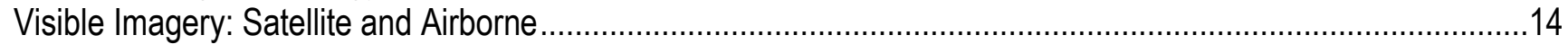

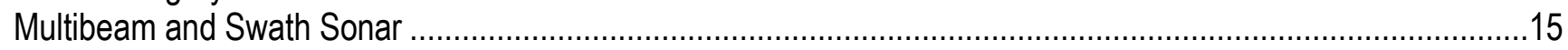

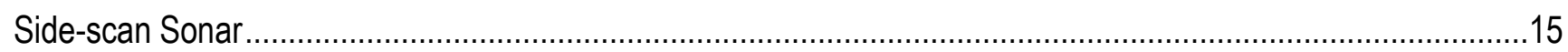

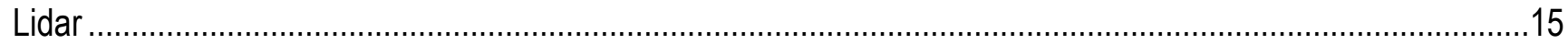

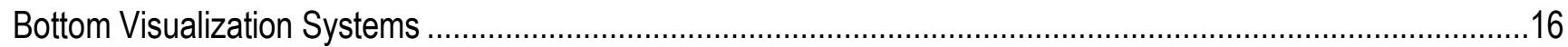

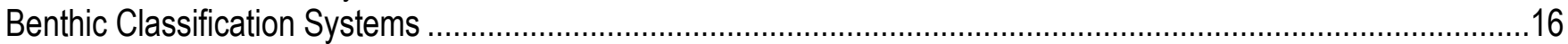

Coastal and Marine Ecological Classification Standard (CMECS) …..........................................................16 
Greene and others (1999; 2007) Deep-Seafloor Classification Scheme

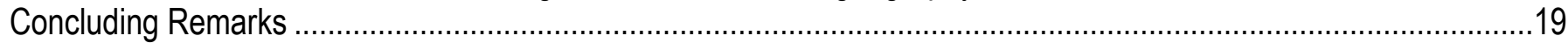

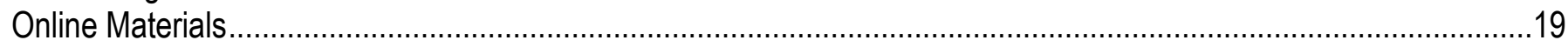

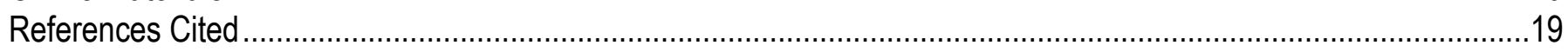

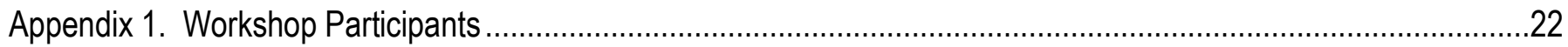

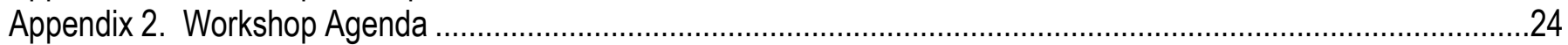

Appendix 3. Ocean and Great Lakes Parks with Submerged Acreage ................................................................28

\section{Figures}

Figure 1. Diagram illustrating the basic types of remote sensing technologies with application to benthic habitat mapping

Figure 2. Diagram of Coastal and Marine Ecological Classification Standard (CMECS) Version III (April 2008) structure 


\section{Abbreviations and Acronyms}

\begin{tabular}{|c|c|}
\hline ACAD & Acadia National Park \\
\hline AKR & Alaska Region of the NPS \\
\hline APIS & Apostle Islands National Leakshore \\
\hline ASIS & Assateague Island National Seashore \\
\hline ATRIS & $\begin{array}{l}\text { Along-Track Reef-Imaging System; A bottom visualization system developed and } \\
\text { deployed by the USGS for benthic mapping and validation. }\end{array}$ \\
\hline AUV & Autonomous Underwater Vehicle \\
\hline AVHRR & Advanced Very High Resolution Radiometer (NOAA satellite) \\
\hline BISC & Biscayne National Park (Florida) \\
\hline BOHA & Boston Harbor Islands National Recreation Area \\
\hline BUIS & Buck Island Reef National Monument (U.S. Virgin Islands) \\
\hline CACO & Cape Cod National Seashore \\
\hline CANA & Canaveral National Seashore (Florida) \\
\hline CCMA & Center for Coastal Monitoring and Assessment (NOAA) \\
\hline CCSWMP & California Coast State Waters Mapping Project \\
\hline CHIS & Channel Islands National Park (California) \\
\hline CMECS & Coastal and Marine Ecological Classification Standard \\
\hline DRTO & Dry Tortugas National Park (Florida) \\
\hline EROS & Earth Resources Observation and Science \\
\hline FGDC & Federal Geographic Data Committee \\
\hline FIIS & Fire Island National Seashore \\
\hline FWRI & Fish and Wildlife Research Institute (Florida) \\
\hline GATE & Gateway National Recreation Area \\
\hline GLBA & Glacier Bay National Park and Preserve (Alaska) \\
\hline GLR & Great Lakes Region if the NPS \\
\hline GOGA & Golden Gate National Recreational Area \\
\hline GOS & Geospatial One Stop \\
\hline GPS & Global Positioning System \\
\hline GUIS & Gulf Islands National Seashore (Mississippi and Florida) \\
\hline IKONOS & Not an acronym; commercial high-resolution satellite operated by GeoEye \\
\hline IMAC & Inventory and Monitoring Advisory Committee (NPS) \\
\hline IMT & Incident Management Team \\
\hline INDU & Indiana Dunes National Lakeshore \\
\hline ISRO & Isle Royale National Park \\
\hline IWG-OCM & Interagency Working Group on Ocean and Coastal Mapping \\
\hline KAHO & Kaloko-Honokohau National Historical Park (Hawaii) \\
\hline KATM & Katmai National Park \\
\hline lidar & $\begin{array}{l}\text { Light Detection and Ranging; An instrument that can be mounted to aircraft and } \\
\text { uses a laser for determining elevation or bathymetry. }\end{array}$ \\
\hline MMU & Minimum Mapping Unit \\
\hline
\end{tabular}




$\begin{array}{ll}\text { MODIS } & \text { Moderate Resolution Imaging Spectrometer (NASA satellite) } \\ \text { MOU } & \text { Memorandum of Understanding } \\ \text { MPA } & \text { Marine Protected area } \\ \text { MWR } & \text { Midwest Region of the NPS } \\ \text { NASA } & \text { National Aeronautics and Space Administration } \\ \text { NER } & \text { Northeast Region of the NPS } \\ \text { NGDS } & \text { National Geophysical Data Center } \\ \text { NMS } & \text { National Marine Sanctuaries division of NOAA } \\ \text { NOAA } & \text { National Oceanic and Atmospheric Administration } \\ \text { NOS } & \text { National Ocean Service } \\ \text { NPS } & \text { National Park Service } \\ \text { NRPC } & \text { Natural Resource Program Center (NPS) } \\ \text { OCRB } & \text { NPS Ocean and Coastal Resources Branch (Ft. Collins, CO) } \\ \text { OLYM } & \text { Olympic National Park } \\ \text { PACM } & \text { Pacific Islands Network } \\ \text { PDF } & \text { Portable Document Format; easily readable digital file format for text and figures } \\ \text { PIRO } & \text { Pictured Rocks National Lakeshore } \\ \text { PORE } & \text { Point Reyes National Seashore } \\ \text { PWR } & \text { Pacific West Region of the NPS } \\ \text { ROV } & \text { Remotely Operated Vehicle } \\ \text { SBMP } & \text { Servicewide Benthic Mapping Program } \\ \text { SER } & \text { Southeast Region of the NPS } \\ \text { SITK } & \text { Sitka National Historical Park } \\ \text { SLBE } & \text { Sleeping Bear Dunes National Lakeshore } \\ \text { SST } & \text { Sea surface temperature } \\ \text { USACE } & \text { U.S. Army Corps of Engineers } \\ \text { USGS } & \text { U.S. Geological Survey } \\ \text { VIIS } & \text { Virgin Islands National Park (U.S. Virgin Islands) } \\ \text { VIMS } & \text { Virginia Institute of Marine Sciences } \\ \text { WAPA } & \text { War in the Pacific National Historic Park } \\ & \end{array}$




\title{
USGS-NPS Servicewide Benthic Mapping Program (SBMP) Workshop Report
}

\author{
By Christopher S. Moses ${ }^{1}$, Amar Nayegandhi², John Brock³, and Rebecca Beavers ${ }^{4}$
}

\section{Executive Summary}

The National Park Service (NPS) Inventory and Monitoring (I\&M) Program recently allocated funds to initiate a benthic mapping program in ocean and Great Lakes parks in alignment with the NPS Ocean Park Stewardship 2007-2008 Action Plan. Seventy-four (ocean and Great Lakes) parks, spanning more than 5,000 miles of coastline, many affected by increasing coastal storms and other natural and anthropogenic processes, make the development of a Servicewide Benthic Mapping Program (SBMP) timely. The resulting maps and associated reports will be provided to NPS managers in a consistent servicewide format to help park managers protect and manage the 3 million acres of submerged National Park System natural and cultural resources. Of the 74 ocean and Great Lakes park units, the 40 parks with submerged acreage will be the focus in the early years of the SBMP.

The NPS and U.S. Geological Survey (USGS) convened a workshop (June 3-5, 2008) in Lakewood, CO. The assembly of experts from the NPS and other Federal and non-Federal agencies clarified the needs and goals of the NPS SBMP and was one of the key first steps in designing the benthic mapping program. The central needs for individual parks, park networks, and regions identified by workshop participants were maps including bathymetry, bottom type, geology, and biology. This workshop, although not an exhaustive survey of data-acquisition technologies, highlighted the more promising technologies being used, existing sources of data, and the need for partnerships to leverage resources. Workshop products include recommended classification schemes and management approaches for consistent application and products similar to other long-term NPS benthic mapping efforts. As part of the SBMP, recommendations from this workshop, including application of an improved version of the Coastal and Marine Ecological Classification Standard (CMECS), will be tested in several pilot parks. In 2008, in conjunction with the findings of this workshop, the NPS funded benthic mapping projects in Glacier Bay National Park and Preserve, Golden Gate National Recreational Area, Sleeping Bear Dunes National Lakeshore, Gulf Islands National Seashore, Virgin Islands National Park, and Virgin Islands Coral Reef National Monument. Full design and protocols of the SBMP based on the findings of this workshop are detailed in a second document dedicated to the subject.

\footnotetext{
${ }^{1}$ Department of Earth and Environment, Florida International University, Miami, FL

${ }^{2}$ Jacobs Technology Inc., St. Petersburg Coastal and Marine Science Center, St. Petersburg, FL

${ }^{3}$ U.S. Geological Survey, Coastal and Marine Geology Program, Reston, VA

${ }^{4}$ National Park Service, Natural Resources Division, Denver, CO
} 


\section{Key Workshop Findings}

- It is essential to inventory benthic resources in order to establish a baseline for managing for future changes and impacts. Protection of resources is impossible without knowing what those resources are.

- Mapping protocols and classification schemes must also incorporate submerged freshwater natural and cultural resources. This omission is the biggest shortfall in existing classification schemes.

- The best existing candidate for a classification scheme is the Coastal and Marine Ecological Classification Standard (CMECS) Version III (May 2008), but the scheme would require substantial modification to fit NPS management needs.

- Influences close to park units can potentially have major effects on resources within a park. Mapping beyond the park unit boundaries is therefore critical for proper management within the park unit.

- Each ocean or Great Lakes park needs an accurate submerged system map (bathymetry, surficial sediments and geology, and salinity and temperature gradients) before detailed habitat mapping can begin (living bottom cover, community structure, population dynamics).

- Map accuracy needs to conform to national standards (>80 percent thematic accuracy and positional accuracy of 1/50th of an inch at a 1:24,000 scale).

- Mapping plans should be standardized after testing SBMP protocols in the pilot parks and before wider application is made to ocean and Great Lakes parks.

- Partnerships with the National Oceanic and Atmospheric Administration (NOAA), USGS, and other State and Federal agencies must be established to leverage finances and coordinate data sharing to accomplish initial mapping.

- Good planning for survey opportunities is essential to map in a timely fashion and avoid duplication of effort.

\section{Essential Recommendations and Conclusions from Presenters}

\section{Programmatic Recommendations and Conclusions}

- George Dickison, NPS Natural Resources Program Center

- Projections show that 92 percent of Phase I inventory programs will be completed by FY10, so now is the critical time to develop the Phase II specialized inventory programs like the SBMP.

- Bill Jackson, NPS Water Resources Division

- There is a pressing need for a seamless network of marine protected areas, but there is no need to reinvent the mapping and inventory process on the way to better management of coastal resources.

- Julia Brunner, NPS Ocean and Coastal Resources Branch

- The primary workshop goal is to create a submerged resources inventory program that helps the NPS understand, monitor, and protect its ocean resources.

\section{Regional Recommendations and Conclusions}

- Charles Roman, NPS Northeast Region (NER)

- The NER faces challenging conditions for mapping, including a diversity of nearshore habitat types found in either the surf zone or in turbid, shallow, back-barrier lagoons. 
- Larry West, NPS Southeast Region (SER)

- The SER has some information mapped, but it is largely not up to date. Moving forward with the current mapping program is essential to those parks.

- Ulf Gafvert, NPS Great Lakes Region (GLR)

- Nearly complete bathymetry of NPS waters in the GLR will be available in 2009, but most other information is missing.

- Penny Latham, NPS Pacific West Region (PWR)

- The Pacific Island parks have been well mapped by NOAA, and the coastal parks are being mapped by State initiatives; however, this does not eliminate the need for further mapping as part of SBMP.

- Scott Gende, NPS Alaska Region (AKR)

- The AKR contains 54 percent of NPS marine shoreline and 40 percent of the marine waters in NPS jurisdiction, but of 10 parks, only Glacier Bay National Park has jurisdiction over submerged resources.

- Essential marine "vital signs" in the AKR depend on interaction between the benthos and the ecosystem.

\section{Recommendations and Conclusions from Mapping Programs}

- Karl Brown, NPS I\&M Vegetation Mapping

- Stabilize the benthic mapping standard early, and revise it only after several pilot parks have tested the standard. Then modify the standard a minimal number of times to make improvements.

- Bruce Heise, NPS I\&M Geologic Mapping

- Focus on producing maps that parks need and avoid the production of maps without a specific management need.

- Scoping meetings, either regional or park specific, are critical to the success of a mapping program.

- Larry Murphy, NPS Submerged Resources

- Determine the primary management responsibilities early in the SBMP (laws, regulations, park objectives, and so on)

- Science-based management of submerged resources is the objective, so the SBMP will need management-based science to succeed.

- Christine Taylor, NOAA National Marine Sanctuaries

- Create a mapping plan based on realistic priorities, but realize the need for priorities to differ from park to park.

- Don't map just because you can - map according to the questions that need to be answered with the data.

- Tim Battista, NOAA Biogeography

- The NPS SBMP needs to develop an applicable classification scheme, maintain scalability, and evaluate existing data for applicability to the current SBMP.

- Becky Allee, NOAA Coastal Services Center

- Version III of the Coastal and Marine Ecological Classification Standard (CMECS) is being submitted to the Federal Geographic Data Committee (FGDC) standards review process as a candidate for the Federal benthic mapping standard.

- It is essential that the NPS and SBMP get involved with the CMECS review process.

- Gary Greene, Moss Landing Marine Lab 
- Marine benthic habitat depends on depth, substrate, [geo]morphology, slope, currents, and biology.

- The Greene and others (1999) deep water classification scheme is flexible and is being incorporated in CMECS.

\section{Data-Management Recommendations and Conclusions}

- Sue McLean, NOAA National Geophysical Data Center (NGDC)

- Map once, use often.

- Robert Pierce, USGS, National Geospatial Program Office

- The Geospatial One Stop (GOS) Marketplace could be beneficial to the NPS SBMP for sharing information on planned surveys. As well as for the GOS database of available benthic data.

\section{Introduction and Background}

\section{Introduction}

Ocean and Great Lakes National Park System unit managers and policymakers face a growing number of complex natural and anthropogenic processes (or stressors), including rising sea surface temperatures (SSTs) (Casey and Cornillon, 2001; Jokiel and Brown, 2004), coastal development (Hooper and others, 2005), erosion, increased nutrient influx (LaPointe, 1997; Hu and others, 2004), and rising sea levels (Done and Jones, 2006), that affect the natural environment within park boundaries. To manage or mitigate any of these threats, benthic resources within and close to park boundaries must be identified and documented.

The boundaries and distribution of terrestrial park features, such as forests, roads, vegetation, and soils, can be readily determined. In many cases, park employees can make daily, weekly, or monthly observations of terrestrial features with basic equipment. However, in subaqueous environments, key benthic environmental features are difficult to assess and map accurately. Such efforts often require expensive and sophisticated remote sensing technology, wherein the results are subject to multiple interpretations and initially lack direct evidence of many biological factors. Resulting maps, therefore, are often limited to indicating "potential" benthic habitats (Greene and others, 2007).

NPS officials recognize the pressing need for a Servicewide Benthic Mapping Program to address the lack of benthic inventory information in most ocean and Great Lakes parks. The Natural Resources Inventory and Monitoring Guidelines (National Park Service) outline the standards expected for NPS Inventory and Mapping programs and products but do not explicitly list different inventories. NPS Natural Resources Management Reference Manual 77 (http://www.nature.nps.gov/rm77/) identifies "marine resource management" as a necessary focus. To manage resources in the benthic environment, managers must identify and characterize the resources. A marine resource inventory and mapping program within the NPS was first addressed at the Geological Resource Division Coastal Mapping Protocol Workshop at Canaveral National Seashore (CANA) in June of 2002 (Nelson and Beavers, 2002). In December 2006, the NPS I\&M Advisory Committee (IMAC) supported a marine mapping program and recognized that mapping ocean and coastal resources requires a dedicated program to address the complex nature of the data collection, processing, and interpretation. A 
Servicewide Benthic Mapping Program (SBMP) with a long-term resource commitment from the NPS I\&M program was recommended.

\section{Need for a Specialized Servicewide Benthic Mapping Program}

The complexity of submerged and coastal benthic environments justifies the need for establishing a separate inventory and mapping program. The technology required to map benthic resources, and the confounded (statistically inseparable) nature of the resources and features, demands consideration under a different program. The technical complications are perhaps most strongly manifested in the cost of working in the marine environment, where data acquisition and processing for a medium-sized park like Golden Gate National Recreational Area (GOGA) or Gulf Islands National Seashore (GUIS) can cost over \$100,000 (G.R. Cochrane, USGS written commun., June 2008). Subsequent validation and interpretation of the remotely collected data add further time and personnel costs.

The issue of confounded resources arises from the interrelatedness of inventories that are easily differentiated on land, for example, surficial geology and vegetation. Acoustic surveys in the marine environment return a bathymetric (depth) value in addition to a reflection coefficient that can be correlated with other bottom properties, such as texture. The bottom substrate can be classified in terms of "hardness" or bottom type (mud or sand), based on a series of derived correlations of reflectivity. The character of the returned signal can also be used to classify/interpret bottom characteristics including seagrass. Benthic habitats by definition include the geology, depth, water quality (temperature, salinity, light availability), surface sediments, and biological components. However, acoustic remote sensing only produces bottom substrate information. Due to the lack of a unique signal interpretation, maps interpreted from acoustic data indicate "potential habitats" rather than actual habitats (Greene and others, 2007).

Nearshore benthic mapping will inventory resources and establish baselines for future monitoring. Mapping products will also guide park managers as they assess post-incident damage (storms, ship groundings, oil spills, or other damage) and provide decision support for recovery options. The benthic maps will document baseline conditions for managers to formulate post-incident mitigation/management decisions. With these products, network or regional I\&M managers will be able to provide Incident Management Teams (IMTs) with the necessary information to manage the park unit resources for recovery.

In addition, coastal areas beyond park boundaries are being heavily and continuously developed. Having accurate inventories up to and beyond park unit boundaries may justify any necessary management actions related to development, such as increasing awareness of the problem in community leaders.

\section{Workshop Proceedings}

\section{Workshop Overview}

The NPS and USGS convened this Servicewide Benthic Mapping Program Workshop of experts, held June 3-5, 2008, in Lakewood, CO, to clarify the needs and goals of the NPS SBMP. Over 3 days, 45 coastal experts and NPS, NOAA, and USGS managers participated in the workshop (appendix 1). Chris Moses (Jacobs Technology/USGS) planned and coordinated the workshop under guidance from Julia Brunner (NPS - Acting Ocean and Coastal Resources 
Branch [OCRB] Chief), Rebecca Beavers (NPS-Geological Resources Division [GRD]), and John Brock (USGS). The moderator was Elisabeth Brouwers (USGS).

On the first day, participants explained the motivation for the workshop and detailed the intended scope of the Servicewide Benthic Mapping Program (appendix 2). The NPS Natural Resource Program Center (NRPC) and regional I\&M coordinators laid out the collective needs for the establishment of the program, as well as guidelines and limitations to its development and deployment. The guidelines and limitations were illustrated with examples of successful strategies from existing I\&M programs, and managers provided insight regarding some of the challenges they faced in other servicewide programs. Technical experts delivered a primer on the major technologies employed for benthic mapping.

On day two, participants described existing marine mapping programs from other agencies (NOAA and the USGS) and delivered a summary of the current strategies for storing and distributing geospatial datasets managed by Federal agencies, such as those that would be collected during the course of the SBMP. Break-out sessions were organized into participant groups that addressed issues (outlined by a list of guiding questions) by latitude (tropical, temperate, high latitude) and freshwater park units. Each of the break-out groups was "crosspollinated" with experts from other regions as well as the region of interest.

Day three opened with reports from the break-out groups followed by considerable discussion at the end of the reports. After wrap-up discussions, the workshop was adjourned around noon. Workshop leaders continued into the afternoon with an after-action review of the workshop results.

\section{National Park Service (NPS) Benthic Mapping Status and Needs}

\section{NPS Need for Benthic Inventory and Monitoring}

Phase I of the NPS I\&M program includes basic inventories that are common to all National Parks (geology, soils, and so on) and is expected to be 92 percent completed by FY10 (http://science.nature.nps.gov/im/index.cfm). Phase I is winding down, and park-specific Phase II inventories are being initiated with partial funding. The NPS I\&M Advisory Committee (IMAC) recommended that a submerged-lands inventory be funded during each of the next 5 years. A fully operational program will require project funding and the leveraging of partnerships with agencies and organizations experienced in benthic habitat mapping. Important issues in a successful I\&M program include quality control, accountability, a standard set of servicewide protocols, and avoidance of duplicate efforts.

This workshop is an outcome of the development and implementation of the NPS Ocean Park Stewardship 2007-2008 Action Plan, which lists the following objectives:

- Objective 1: Establish a seamless system of ocean parks.

- Objective 2: Discover, map, and protect ocean parks.

- Objective 3: Engage visitors in ocean park stewardship.

- Objective 4: Increase NPS technical capacity for ocean exploration and stewardship.

The NPS is developing memoranda of understanding (MOUs) with other Federal and State agencies to share in mapping, management, and law enforcement activities for National Parks and other marine protected areas (MPAs). Objective 2 includes the completion of benthic maps for ocean parks and is supported by Objective 4, which develops the capacity for inventory 
and mapping of the benthic habitats in coastal parks. The corresponding NPS Regional Stewardship Action Plans all emphasize the need for marine mapping.

The NPS has 390 park units, 74 of which include marine or Great Lakes waters with $>5,000$ miles of coastline (appendix 3). The 40 ocean and Great Lakes parks with submerged acreage cover intertidal zones to water depths of $>1,000$ meters, as well as latitudes from tropical to sub-arctic. These ocean and Great Lakes parks with submerged acreage contain a mix of natural and cultural resources that fall under the NPS Organic Act of 1916 mandate to conserve and protect. Similar to many of the terrestrial park units, conflicting issues frequently arise in ocean and Great Lakes parks from multipurpose use (fishing, navigation, coastal development, and so on) to complications from multi-agency or limited NPS jurisdiction.

The NPS lacks fundamental baseline data, such as submerged bathymetry, geology, and major biological communities, for most ocean and coastal parks. For example, the U.S. Army Corps of Engineers (USACE) and the State of Mississippi are planning a restoration project for Gulf Islands National Seashore (GUIS) without complete benthic substrate or habitat information for the park. The final map products required by park managers need to characterize the submerged areas of the park without gaps. Since the terrestrial maps usually end at mean high water, benthic information needs to be seamlessly integrated into the terrestrial maps, especially in areas with substantial tidal ranges and flourishing intertidal communities.

These basic data need to be collected and distributed in an easily accessible format to plan management strategies, address change, and mitigate negative impacts. It would be beneficial if the NPS established an advisory committee to coordinate the SBMP with programs in other agencies (especially NOAA and the USGS) and State government programs (California Coast State Waters Mapping Project [CCSWMP] and Florida Mapping Implementation Plan).

\section{Overview of Benthic Inventory and Monitoring in NPS Units}

\section{Northeast Region (NER)}

The SBMP is important at regional, network, and park unit scales. Applications for SBMP in the NER focus on benthic habitats around barrier islands and estuaries. The NER stretches from Maine to Virginia and has made it a high priority to move ahead with its own program to inventory, map, and understand the available submerged natural and cultural resources. Inventory and mapping of submerged resources has been completed to 75 percent at Fire Island National Seashore (FIIS), 60 percent at Gateway National Recreation Area (GATE), and 40 percent at Cape Cod National Seashore (CACO). Despite these successes, particular challenges to benthic habitat mapping in the NER include the broad diversity of habitat types and the extensive, turbid, back-barrier lagoons. Examples include Acadia National Park (ACAD), which is dominated by a complex rocky intertidal zone, and Boston Harbor Islands National Recreation Area (BOHA), which includes 34 islands and 35 miles of shoreline (51 percent in the intertidal zone).

Many National Parks are not completely mapped in the NER. For example, Assateague Island National Seashore (ASIS) is $>60$ percent marine and estuarine by area, but only about 25 percent of the marine bathymetry has been mapped through partnership with the USACE whereas 100 percent of the estuarine bathymetry was mapped in partnership with the Maryland Geological Survey. Seagrass was mapped by aerial survey in cooperation with the Virginia Institute of Marine Science (VIMS), but only for estuarine areas. None of this material is compiled into a formal benthic habitat map or was mapped in a consistent framework. 
It is essential to know what is present in order to establish a baseline for managing future changes and impacts. Protection of the resources is impossible without knowing what those resources are. Challenges are often presented by data shortfalls that frustrate or prohibit management action or by migrating barrier islands that create legal jurisdiction issues for mapping and enforcement.

\section{Southeast Region (SER)}

The SER has numerous parks with submerged acreage, including Biscayne National Park (BISC), Dry Tortugas National Park (DRTO), Buck Island Reef National Monument (BUIS), and Virgin Islands National Park (VIIS). Canaveral National Seashore (CANA) contains substantial submerged resources, including estuarine and marine areas, and extends more than a half mile $(0.8 \mathrm{~km})$ offshore. Much of the benthic mapping efforts in these park units has been in cooperation with State agencies and NOAA. NOAA completed benthic habitat maps for VIIS and BUIS, whereas the Florida Fish and Wildlife Research Institute (FWRI) has been instrumental in benthic habitat mapping at BISC and DRTO.

BISC and DRTO have been characterized, and the existing benthic maps are being updated with additional data collection and interpretation. Aerial photography of the entire BISC, and Light Detection and Ranging (lidar) bathymetry along the southern portion, are augmenting the existing benthic maps. DRTO has zonation and geologic maps, as well as aerial photography from 2003, lidar collected in 2004, and IKONOS satellite imagery (4-m resolution) obtained by NOAA in 2007. These products have been used to select sampling sites and to model coral community changes through time.

It is important that the SBMP establish goals and deliverables to permit accurate comparison between park units and between dates. NPS needs to resolve confusion over jurisdictional boundaries for submerged park units. Parks in the SER have ranked aquatic vegetation as a high priority and want to inventory seagrass and hardbottom, including oyster reefs. Other SER products that would aid in managing the parks include hazards and vulnerability maps (areas vulnerable to breaching or overwash during storms). Sources of data in the SER include the State of Texas, where data mining could leverage large amounts of applicable information.

Midwest Region (MWR)

The Great Lakes and MWR contain parks with submerged acreage including Apostle Islands National Lakeshore (APIS), Indiana Dunes National Lakeshore (INDU), Isle Royale National Park (ISRO), Pictured Rocks National Lakeshore (PIRO), and Sleeping Bear Dunes National Lakeshore (SLBE). In fact, ISRO has the fourth greatest area of submerged resources in the NPS, with $1,752 \mathrm{~km}^{2}$ of Lake Superior. Unlike many coastal park units that have a boundary at mean high tide, many Great Lakes park units have a buffer that extends $400 \mathrm{~m}(1 / 4$ mile) offshore. The NPS Ocean Park Stewardship 2007-2008 Action Plan includes Great Lakes parks among coastal parks, and all of them have substantial submerged resources.

The USACE is acquiring lidar topography $500 \mathrm{~m}$ landward and $1 \mathrm{~km}$ lakeward along the Great Lakes (not restricted to park boundaries). The product is a bathymetric map with 5-m spatial resolution to a depth of $2.5 \mathrm{x}$ Secchi disc depth (>20 $\mathrm{m}$ in optimal conditions). The resulting data are shared through USACE with the NOAA National Ocean Service (NOS), National Geophysical Data Center (NGDC), and Geospatial One Stop (GOS), making it widely available. 
None of the Great Lakes park units is completely mapped for bathymetry, submarine geology, benthic habitats, or submerged cultural resources. The Great Lakes parks require detailed classification of lacustrine benthic systems that are not accommodated in any of the widely applicable classification systems, such as CMECS (Madden and others, 2008) or the Greene and others (2007) scheme. Systems such as CMECS can be modified to include the necessary components to address classification of freshwater systems. Such modifications should include classifications for lake trout spawning areas, Cladophora algae, invasive zebra mussels (Dreissena polymorpha), lake currents, and nearshore fish inventories.

\section{Pacific West Region (PWR)}

The PWR has successfully leveraged partnerships to produce benthic habitat maps for much of its large geographic scope. Coastal and ocean park units in the PWR include Olympic National Park (OLYM), Point Reyes National Seashore (PORE), and Channel Islands National Park (CHIS), as well as parks in Hawai 'i, Guam, and American Samoa. Much of the existing mapping work has been accomplished through partnerships with NOAA. All 11 NPS Pacific Islands Network (PACN) parks have benthic maps resulting from collaborations between NPS and NOAA; these maps contain 32 distinct benthic habitat types in 12 zones.

Benthic maps for Kaloko-Honokohau National Historical Park (KAHO), on the Big Island of Hawai'i, were created independently by NOAA and the USGS with NPS funding (Gibbs and others, 2007). Similar patterns of habitats are delineated but are described differently. The resulting confusion can be resolved by using similar nomenclature in the characterization of features or habitats. Benthic habitat maps have also been created for CHIS with side-scan sonar and bottom video imagery by NOAA, USGS, and the State of California (Cochrane and others, 2003; 2007). Like CHIS and KAHO, many areas of the PWR have been mapped by different agencies with different goals. Coordination and leveraging between agencies could serve multiple purposes and maximize resources where mapping is required over broad geographic regions.

\section{Alaska Region (AKR)}

The AKR has 10 coastal parks containing more than 2,800 miles of coastline within park boundaries, making it one of the most extensive coastal regions. The AKR parks with submerged acreage are Glacier Bay National Park (GLBA), Katmai National Park (KATM), and Sitka National Historical Park (SITK), but GLBA is the only park unit with substantial jurisdiction over submerged resources ( 3 miles seaward of mean high water). At this time, several agencies, including the NPS and USGS, are working to complete large-scale mapping and marine ecosystem projects in GLBA.

AKR parks are particularly affected by climate change; thus it is critical to monitor "vital signs" of the health of the park units. Benthic maps are an important first step toward understanding and predicting the distribution of critical components of the Alaska marine biological community, such as the location of baitfish relative to the bird populations that depend on them for food. Proper management of AKR submerged resources requires a good understanding of benthic-pelagic-terrestrial ecosystem linkages.

\section{Prior and Existing NPS Mapping Programs}

Prior and existing NPS Phase I I\&M programs such as Vegetation Mapping and the Geologic Resource Inventory, and the corresponding coordinators, have more than a decade of 
experience performing inventories in National Parks. This valuable experience is a foundation for the Phase II inventories, such as the SBMP.

\section{NPS Vegetation Inventory and Mapping Program}

The vegetation mapping program is one of the oldest and highest priority servicewide I\&M programs. Vegetation mapping meets immediate needs for each park unit as well as begins long-term vegetation monitoring for that particular park. The NPS servicewide vegetation mapping applies a nationally consistent hierarchical, classification standard that meets Federal Geographic Data Committee (FGDC) standards. Among the lessons learned from the vegetation mapping program is that consistent standards are more important than application of particular technologies. The ideal process includes the following predictable series of steps for each park in the program: (1) scoping meeting, (2) data review/data mining, (3) new data acquisition (if needed), (4) interpretation and mapping, (5) accuracy assessment, and (6) series of GIS products and reports. The final report and the map products are the most important deliverables in the process. More information on the products can be found at http://biology.usgs.gov/npsveg/.

The current NPS vegetation mapping program has undergone some recent changes, including adding "macrogroup" and "group" as two new levels in the standard. These new classes are part of the FGDC National Vegetation Classification Standard 2006 revision. The final vegetation maps must meet the National Map Accuracy Standards for positional accuracy and the minimum classification accuracy of 80 percent across all vegetation and land cover classes. With 40 parks completed and 167 projects in progress (June 2008), the massive amount of data is archived at the USGS Earth Resources Observation and Science (EROS) Data Center.

\section{NPS Geologic Resources Inventory and Mapping}

The original I\&M geological mapping program did not include a separate inventory of submerged or coastal resources. The original program was park specific, but the final reports and GIS materials are similar. Each final report is also customized with a section highlighting the regional and local geologic setting to place the report in the appropriate geologic context. Scoping summaries for almost all coastal parks are available.

Initial mapping of CANA and GUIS barrier island parks highlighted an unanticipated problem. On typical geologic maps, barrier islands and surrounding coasts (on passive continental margins) tend to map as a single geologic unit $Q^{*}$, where $Q$ represents a Quaternary geologic unit and the * would be replaced by a one- or two-letter abbreviation for the name of the unit. For a park like CANA that is entirely coastal, this convention produces a nearly useless or completely useless geologic map because it has only one or two classes. An interagency workshop was held in 2002 at CANA to determine how best to add value to a coastal geologic map. The workshop suggested a set of protocols, some of which can be translated directly to the SBMP to add value without duplicating effort. Integrated terrestrial and submerged maps, such as the geologic resources map of VIIS, provide an excellent example of a merged product with added value.

\section{NPS Submerged Resources Program}

The NPS Submerged Resources Center applies underwater archaeology to study social processes. This includes socially important sites, such as historic known wrecks (USS Arizona Memorial), and some unknown wrecks in parks like DRTO. The socially important submerged 
resources also include sites of previous settlement, such as Apra Harbor at War in the Pacific National Historical Park (WAPA).

Some of the sites are very well preserved, and some historic sites are entirely submerged. The sensitive legal, religious, and cultural nature of many of these resources demands discretion because of public access to the final mapping products. Inclusion of cultural resources attributes in the SBMP classification scheme is necessary, but challenging, due to the sensitive nature and the often necessarily small scale.

\section{Other Agency Mapping Programs, Classification Schemes, and Geospatial Data Networks}

\section{NOAA National Marine Sanctuaries Mapping Program}

The NOAA National Marine Sanctuaries (NOAA-NMS) maintain their own benthic habitat mapping program coordinated with the NOAA Biogeography Branch. The National Marine Sanctuaries span nearly the same geographic range as the NPS coastal park units with the exception of the freshwater parks. NOAA-NMS does not use a consistent classification scheme in part because of the diversity across the geographic range of the sanctuaries.

NOAA-NMS methodology recommends the following: (1) data mining for each park unit as it becomes a mapping priority, (2) defining management priorities for the park, and (3) focusing the map products to meet those needs. Creating a GIS priority map for each region or network increases efficiency and helps with planning. It highlights opportunities, resources that can be shared, and existing data.

\section{NOAA Tropical Marine Mapping Program}

The NOAA Center for Coastal Monitoring and Assessment (CCMA) Biogeography Branch has a unit that focuses specifically on tropical marine biogeography and predictive modeling. NOAA collects a suite of remotely sensed acoustic and optical data for habitat characterization. The processed data are passed through a comprehensive and consistent mapping system with a robust, well-tested habitat classification scheme.

NOAA CCMA Biogeography has established the following five-step mapping process for marine areas: (1) optical or acoustic data are used to define polygon boundaries in GIS by visual interpretation, (2) polygon boundaries are validated and logged into the GIS, (3) a draft map is created by applying benthic habitat classifications to the validated polygons, (4) the benthic habitat classification is validated, and (5) the draft map is edited by experts before being released for circulation. This system (NOAA-CRCP, 2008) has been widely applied from Florida to the U.S. Virgin Islands (VIIS and BUIS), to Hawai' $i$, and to other tropical Pacific Islands. A new semi-automated seafloor-mapping method developed to speed up the process is currently in the testing phase.

\section{Enterprise Mapping, Data Storage, and Data Sharing}

The cross-cutting theme for data management, storage, and sharing is "Collect once, use often." The NPS Data Store, NOAA-NGDC, and Geospatial One-Stop (GOS) are warehouses for distributed geospatial datasets and metadata. Web-based environments allow these sites to tie many different data types into a common interface. The success of any of these data clearinghouses depends on researchers and agencies regularly updating the links and lists of 
available data. The NPS Data Store is set up to be the first stop for completed SBMP data and products before linking out to GOS (http://geodata.gov).

The Interagency Working Group for Ocean and Coastal Mapping (IWG-OCM or IOCM) has increased the efficiency of ocean and coastal mapping activities by reducing duplication of effort, building partnerships, and providing mapping data through a common website regardless of the collection agency. As a result, several Federal agency data servers are now coordinating to share all of their data through GOS. GOS has a section called the "Marketplace" where information on upcoming surveys can be found. With about 2,500 records (June 2008), the Marketplace is designed to foster collaboration and leverage partnerships to reduce unnecessary duplication of effort. As the SBMP moves forward, the GOS Marketplace will provide a key source of interaction between agencies and mapping groups.

\section{Feedback from Break-out Groups}

\section{Purpose and Structure}

Workshop products were created by participants in break-out sessions. The sessions were long enough (3.5 hours) to produce significant products, and each participant attended a single break-out group only. The full scope of the results from the break-out groups in this workshop are being published in a separate report, which details the recommended mapping standards process for the NPS SBMP (Moses and others, in press). The charge for the break-out groups was to address the benthic mapping needs, challenges, and potential in their designated latitudinal zone. Groups were also responsible for describing the best style of classification system for their region, being specific about features of the classification scheme.

Groups were divided by latitudinal zones into tropical $\left(0^{\circ}-30^{\circ}\right.$ latitude $)$, temperate $\left(30^{\circ}\right.$ $45^{\circ}$ latitude), high latitude ( $>45^{\circ}$ latitude), and freshwater (any latitude, but mostly the Great Lakes). NPS intends to test the SBMP in at least one pilot park in each of these zones. A common set of guiding questions was provided to help focus critical thinking about application of the SBMP in each zone.

\section{Issues Common to All Zones}

- Omission of submerged freshwater natural and cultural resources is the biggest shortfall of the major mapping protocols and classification schemes. The CMECS and the Greene and others (1999) classification schemes should be expanded to incorporate these necessary descriptors.

- Map beyond the park unit boundaries. For example, dredging in an area $1 \mathrm{~km}$ upstream of a park unit could cause an increase in sedimentation within the boundaries of the park unit or could disrupt seagrass beds that are the nursery for many of the fish within the park.

- An accurate submerged-system map (bathymetry, surficial sediments and geology, and salinity and temperature gradients) for each coastal and ocean park should be useful before detailed habitat mapping begins (living bottom cover, community structure, population dynamics, and so on). Basic surveys often exist, but extensive data mining and gap analysis are needed for each park unit prior to beginning a mapping plan.

- Mapping plans can be standardized after SBMP protocols are tested in the pilot parks and before wider application is made to ocean and coastal parks. 
- Partnering with NOAA, USGS, and other State and Federal agencies at IGW-OCM meetings would help leverage finances and coordinate data sharing to accomplish initial mapping.

- Survey opportunities benefit from good planning. NPS can offer partners assistance with lodging, permitting, and personnel. A GIS map of priority areas and their needs (for each I\&M region) would increase preparedness when a partner offers benthic mapping services on short notice.

\section{Tropical Zone}

Tropical zone break-out participants described a flexible classification scheme and emphasized the need to be able to crosswalk (provide a conversion from one classification scheme to another) with the many existing tropical benthic classification schemes. In particular, this group felt that the NOAA-Biogeography classification scheme was better adapted for this environment than CMECS or the Greene and others (1999) schemes. Other specific considerations included the need for high accuracy ( $>80$ percent) and the urgency to get NPS tropical benthic mapping needs in GOS as soon as is feasible.

\section{Temperate Zone}

The temperate zone break-out group saw value in a bottom-up classification system (a system that begins with geology to define biologic communities) that could be customized to fit the needs of each park unit. The report stressed the importance of mapping biotic and abiotic factors. The group also suggested the possibility of independent benthic surveys and inventories for features like bathymetry and cultural resources.

\section{High-Latitude Zone}

High-latitude park managers need to identify the most critical biological communities to prioritize and structure benthic mapping. A combined CMECS and Greene and others (1999) scheme would be effective in most high-latitude areas if it incorporates a mechanism to use discrete point data rather than using polygons exclusively. In some areas, the data are and will continue to be sparse. High-latitude parks may have substantial tidal ranges requiring accommodation in benthic habitat maps. Because large ranges in water depth are involved, the resolution of remote sensing technologies would vary, possibly requiring a gradient of resolutions from fine (nearshore) to coarse (deep water).

\section{Freshwater Coastal Zone (Great Lakes)}

The freshwater-zone participants would give parks in the Great Lakes priority among freshwater parks in the inventory and mapping program, followed by other major lakes, then finally streams and rivers. These regions frequently lack basic GIS information such as bathymetry. CMECS seems to have a good structure for application in freshwater parks, but development and testing will be necessary before freshwater components can be classified. Water column structure is very important in lakes and would be a useful map layer. The high degree of variability between freshwater park units will make a uniform, servicewide benthic mapping program challenging. 


\section{Benthic Mapping Technology and Classification Primer}

\section{Benthic Mapping Technology}

The ability to produce accurate benthic maps is necessarily dependent on existing technologies. However, benthic mapping should not be dictated by what technology is available, but rather by the needs of the targeted map user. Some benthic mapping technologies are well tested and reliable, whereas others are rapidly advancing and experimental, or are plagued with substantial uncertainties. The fundamental technologies fall into a few basic categories: visible imagery, acoustic data, and bottom visualization (fig. 1).

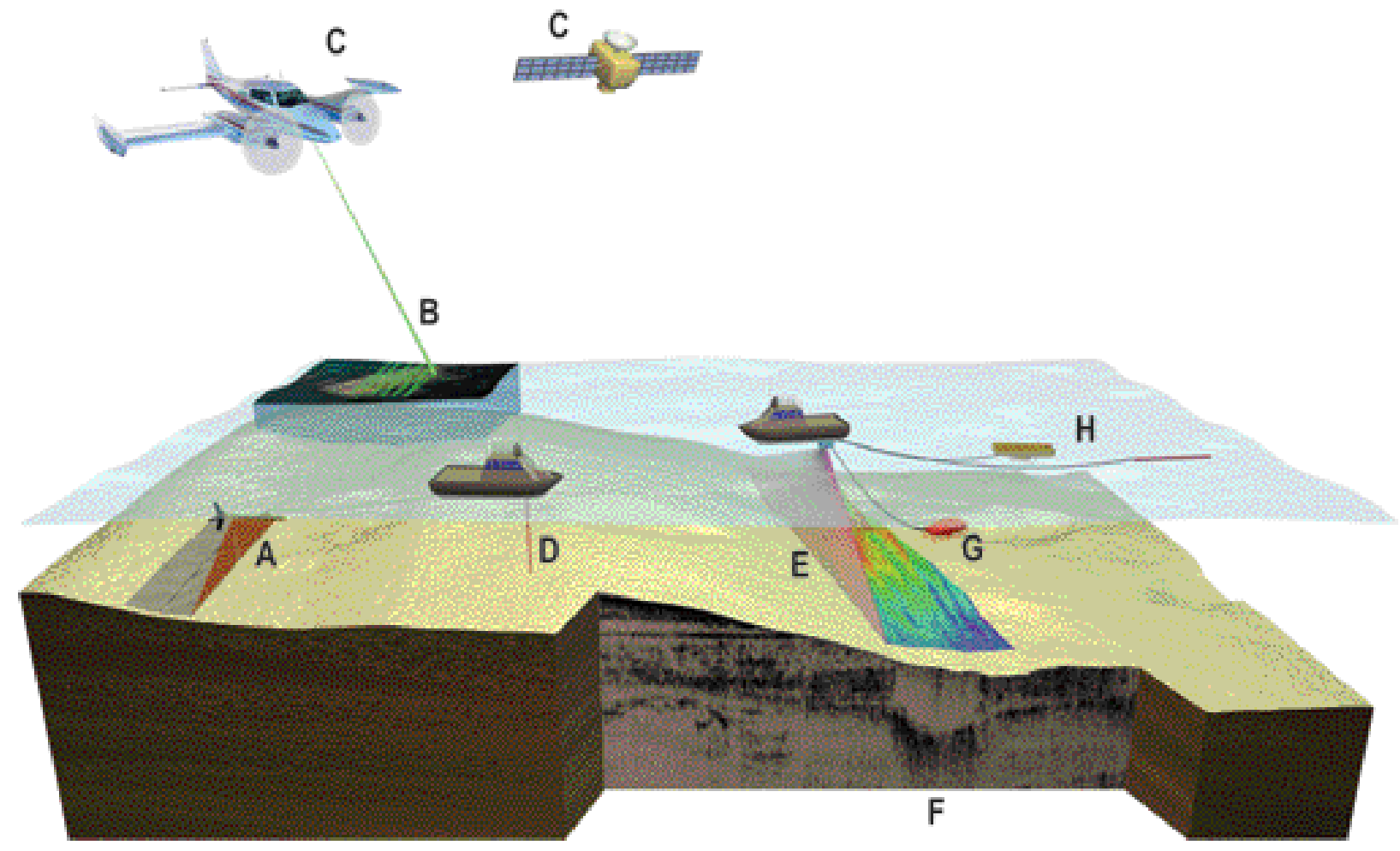

Figure 1. Diagram illustrating the basic types of remote sensing technologies with application to benthic habitat mapping. (A) Side-scan sonar; (B) Lidar; (C) Color aerial or satellite imagery; (D) Single-beam sonar; (E) Multibeam or swath sonar; (F) Seismic acquisition; $(G)$ Bottom visualization; $(H)$ water column data collection, and other devices. Note exaggerated differential uses between the shallow and deep ends of the diagram.

Visible Imagery: Satellite and Airborne

Satellite and aerial imagery are useful for studying a range of ocean and coastal features, such as sea surface temperature (SST), bottom structure/potential habitat, and upwelling over scales ranging from $<1 \mathrm{~m}^{2}$ to $100 \mathrm{~km}^{2}$ or more. Multispectral sensors typically measure the energy in several discrete sections of the visible spectrum, and sometimes in the infrared spectrum, which is useful for vegetation mapping and necessary for SST measurements. 
Satellites carrying multispectral sensors have polar orbits that bring them over most of the planet at least once per day.

Multispectral sensors like the NASA Moderate Resolution Imaging Spectrometer (MODIS) and the NOAA Advanced Very High Resolution Radiometer (AVHRR) satellites provide SST and information on bottom features with a spatial resolution of $\sim 1 \mathrm{~km}^{2}$. Higher resolution multispectral sensors, such as Landsat (30-m spatial resolution) and IKONOS (4-m spatial resolution), can be used to map submerged resources in shallow (generally $<20 \mathrm{~m}$ ), clear waters (Andréfouët and others, 2005).

Airborne sensors operate much in the same way as the satellite sensors but can generally provide resolution measured in centimeters because the distance to the target is shorter. Airborne sensors also require shallow, clear water for penetration and detection. Airborne sensors can be particularly useful in coastal environments with high spatial or temporal variability.

\section{Multibeam and Swath Sonar}

Multibeam sonar systems use sound produced and recorded through an array of transducers to produce high-resolution three-dimensional images of the ocean floor. Multibeam sonar systems are particularly useful in deep water because of the wide swath covered by the system; however, the resolution is less than in shallow water. The swath of the beam is proportional to the water depth, which means that more passes are needed to map shallower areas, thus decreasing the efficiency of the technique and increasing the acquisition cost per unit area.

Multibeam sonar provides depth to the bottom and information about surficial bottom properties, such as hardness and texture. Multibeam systems have been useful in mapping potential benthic habitats in a wide range of environments (Poppe and others, 2005; Lundblad and others, 2006; Cochrane and others, 2007; Greene and others, 2007).

\section{Side-scan Sonar}

Side-scan sonar operates on the same principles as multibeam sonar, but, rather than being mounted on the ship, the instrument is typically towed behind the ship below the water surface and is generally more expensive. The transducers for side-scan sonar are aligned to look more sideways than downward, and the device has a "blind spot" immediately below it. Sidescan sonar is effective in shallower waters because it can detect wide areas from only a short distance above the bottom. This technique also allows strong detection of three-dimensional bottom features. Side-scan sonar data and backscatter information have been useful in numerous coastal applications from port security (Quintal and others, 2007) to studies of coral bleaching (Collier and Humber, 2007).

\section{Lidar}

Lidar can be used in optically shallow water (for example, shallow enough for the sensor to detect the bottom). The light waves from a green laser are reflected from the bottom, and the travel time is used to calculate distance to the bottom. Lidar devices are typically mounted on aircraft, though they can also be ship mounted. One advantage of lidar systems over other marine systems is that they can be used over land as well as in the water, allowing simultaneous mapping of topography across the entire coastal zone. Depending on the needs, laser system, 
and environmental conditions, spatial resolution can range from 1 to $10 \mathrm{~m}$, and vertical resolution from 10 to $15 \mathrm{~cm}$. Lidar has been used successfully to map U.S. coastlines, including in National Parks (DRTO, Biscayne National Park, FIIS).

\section{Bottom Visualization Systems}

The bottom must be directly imaged to validate classifications based on data from remote sensing systems (acoustic). Different types of bottom visualization systems are available for this task, including simple methods (scuba divers) and technologically complex methods (remotely operated vehicles [ROVs]), and each has advantages and limitations. Towed camera systems are commonly used to validate remotely sensed data (Anderson and others, 2007; Zawada and others, 2008).

The Along-Track Reef-Imaging System (ATRIS), developed by the USGS Coastal Marine Geology Program in St. Petersburg, is a bottom-imaging camera system that can either be mounted to the vessel directly for shallow-water operations or towed at depth for moderate depth operations (maximum depth $\sim 25 \mathrm{~m}$ ). The system was developed to provide ground truth data for remotely acquired data, but has evolved into a primary source of data (Lidz and others, 2008; Zawada and others, 2008). The camera system records high-resolution digital images at up to 20 frames per second with a Global Positioning System (GPS) location stamp on each image for very accurate image placement.

\section{Benthic Classification Systems}

\section{Coastal and Marine Ecological Classification Standard (CMECS)}

Scientists at NOAA and NatureServe developed the Coastal and Marine Ecological Classification Standard (CMECS) to fill the need for a Federal standard benthic classification scheme that spans the different ecological regions of U.S. coastlines, and is applicable across scales from $1 \mathrm{~m}^{2}$ to $10,000 \mathrm{~km}^{2}$ (Madden and others, 2005; Madden and others, 2008). The most recent version (Version III, April 2008) of CMECS (Madden and others, 2008) has been updated to align it with current Federal standards for wetlands mapping (Cowardin and others, 1979) and vegetation mapping (Jennings and others, 2009). CMECS Version III (Madden and others, 2008) incorporates much of the scale structure and nomenclature from the Greene and others deep-seafloor classification scheme (Greene and others, 1999; 2007). In October 2008, Version III was proposed to the FGDC for approval as the Federal benthic habitat classification standard. The approval process is expected to take several years.

CMECS Version III is developed around three components that exemplify the coastal and marine habitats - benthic cover, geoform, and water column (fig. 2). The benthic cover component represents the geologic and biotic cover of the substrate at different scales in a hierarchy. The top level of the benthic cover component is divided into five "systems" based on depth, enclosure, and salinity - nearshore, neritic, oceanic, estuarine, and freshwater influenced. Note that freshwater influenced does not include completely freshwater systems such as lakes and rivers. The next level down - "subsystem" - reflects the tidal regime. Below subsystem, the remaining levels (in descending order) are cover type, class, subclass, group, and biotope (fig. 2). 


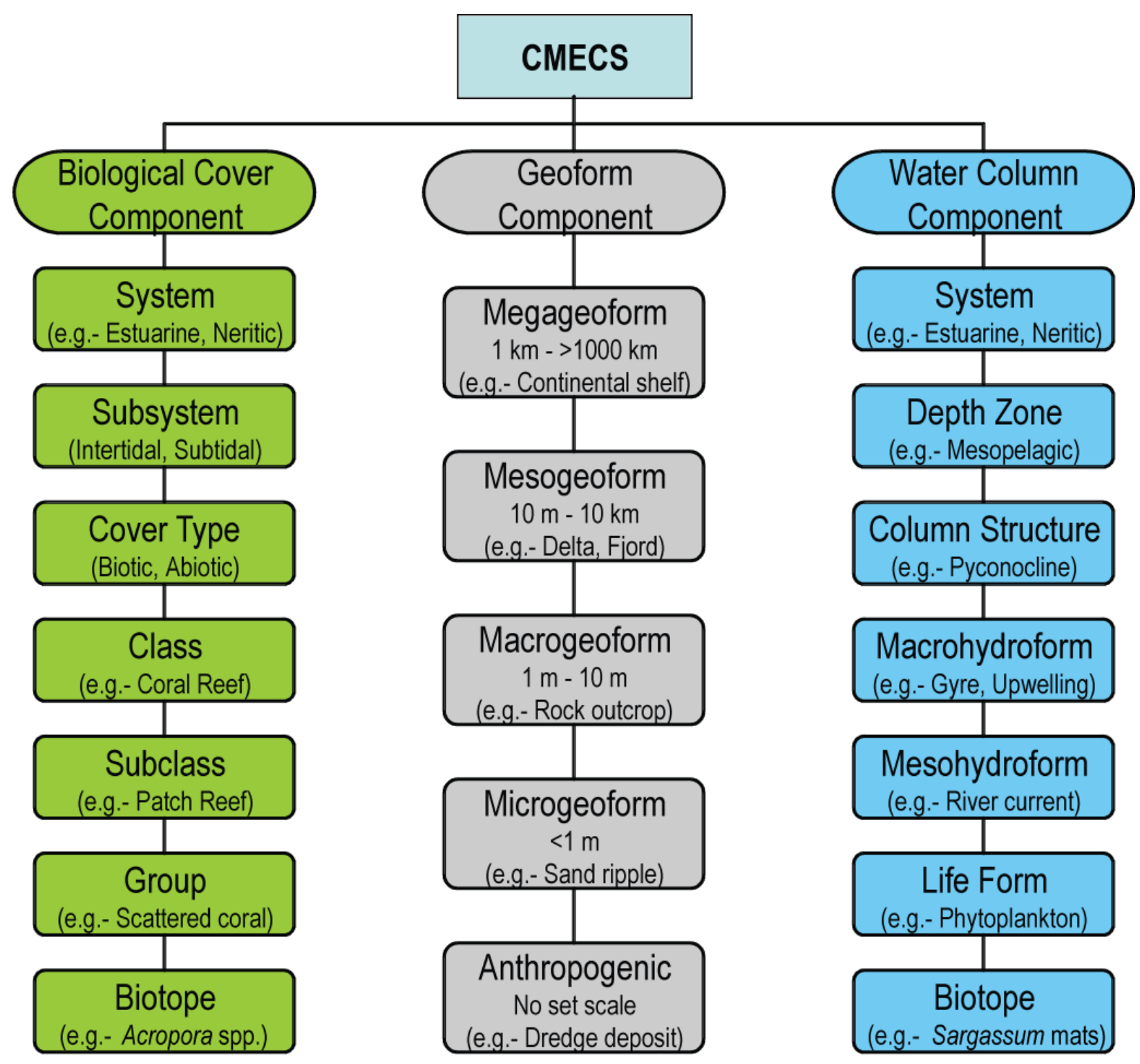

Figure 2. Diagram of Coastal and Marine Ecological Classification Standard (CMECS) Version III (April 2008) structure. Each column represents a separate map layer.

The geoform component describes the structure of the seafloor across a range of scales from meters to thousands of kilometers. The classification framework for the geoform component is derived from Greene and others (2007); however, within the CMECS Version III scheme, the geoform component covers a wider range of nearshore features. Geoform components are critical to controlling the flow of energy (currents and tides) and movement of organisms and connectivity of populations.

The water column component is defined by a series of classifiers that can be used alone or in combination to reflect the structure and processes within the water column. The first level uses the same "systems" as the benthic cover component (estuarine, neritic), and classifiers can be added to represent features such as vertical stratification, currents, and so on. Because the 
water column is dynamic (seasonal changes in temperature and salinity, tidal cycles), only the most prominent and predictable hydrographic features can be used for mapping.

\section{Greene and others (1999; 2007) Deep-Seafloor Classification Scheme}

Although many specialized systems have been developed to classify highly variable habitats in depths from 0 to $30 \mathrm{~m}$ (the NOAA CCMA Biogeography scheme for coral reefs), much less has been done in more uniform environments from 30 to $300 \mathrm{~m}$ (or deeper), where much of the habitat critical to commercial fisheries exists. Greene and others (1999) developed a scheme, modified from Cowardin and others (1979), for deep-seafloor habitats in northernlatitude deeper waters that can be applied in shallow, nearshore, and even tropical regions (Greene and others, 2007; Madden and others, 2008).

This modified classification scheme is organized by scale, but is not hierarchical. Scale, and the ability to resolve geomorphic features of given sizes by remote sensing (sonar, Autonomous Underwater Vehicle (AUV), ROV), limits the classification of potential habitats in progressively deeper water. To address this problem, Greene and others (1999) divided potential habitats into the following four scales summarized in Greene and others (2007):

- Megahabitat - a large feature that ranges in size from a few kilometers to tens of kilometers, and larger. Megahabitats lie within major physiographic provinces, such as the continental shelf, continental slope, or abyssal plain. These features can be depicted with small-scale $(1: 1,000,000$ or greater) bathymetric maps and satellite topographic images.

- Mesohabitat - a feature that ranges in size from tens of meters to kilometers, such as small seamounts, canyons, and extensive bedrock outcrops. These features can be identified with geologic or geomorphic maps and bathymetric images of the seafloor at scales of 1:250,000 or less.

- Macrohabitat - a feature that ranges in size from 1 to $10 \mathrm{~m}$, such as large boulders, reefs, bedrock outcrops, and bedforms (sediment waves). These features can be shown with sediment or geologic maps and bathymetric images of the seafloor at scales of 1:50,000 and less. In addition, macrohabitats can be identified with in situ observational data, such as video and photographs. Biogenic structures, such as sponge or coral reefs, algal mats, and kelp beds, are macrohabitats.

- Microhabitat - a feature that ranges in size from centimeters to $1 \mathrm{~m}$ and consists of mud, sand, gravel, pebble, cobble (sometimes forming pavements), small boulders, interfaces and cracks, and crevices in bedrock outcrops. Individual biogenic structures, such as corals and anemones, are microhabitats.

Potential habitats are defined by a unique series of characters that are used for GIS attribute codes and that allow direct comparison between habitats in different areas. Megahabitat is the first primary character (mandatory), such as " $\mathrm{S}$ " for shelf in depths from 0 to $200 \mathrm{~m}$. The second primary character (mandatory) relates to bottom induration or hardness, such as "Ss" (soft sediment on the shelf in depths of 0 to $200 \mathrm{~m}$ ). The third primary character is the first optional character and indicates the meso- or macrohabitat. Continuing with this example, "Ssc" would be the code for a canyon on a shelf from 0 to $200 \mathrm{~m}$ depth with soft sediment. This nomenclature allows seven primary characters (including codes for seafloor slope, texture, and biology) with potential modifiers. 
NOAA Center for Coastal Monitoring and Assessment Biogeography Coral Reef Classification Scheme

The NOAA Center for Coastal Monitoring and Assessment (CCMA) Biogeography Branch has developed a coral reef classification scheme for application in the tropical waters of the United States (http://ccma.nos.noaa.gov/about/biogeography/). This hierarchical scheme has been applied to reefs in Florida, the U.S. Virgin Islands, and Hawai' $i$ and varies slightly between the Pacific and Florida/Caribbean versions to accommodate the different biotopes found in those regions.

The scheme has three attribute classes beginning with geomorphology (aggregate reef, spur and groove), which alludes to the shape of the feature. The zone attribute (forereef, backreef, lagoon) implies the positional relationship within the reef system. The biological cover attributes (seagrass, 10-50 percent coral cover) describe the biotic components covering the particular geomorphologic structure in the indicated zone.

NOAA Biogeography is working closely with the NOAA CMECS team to merge the two classification systems for coral reef environments. At this time, there are numerous extant maps of coral ecosystems mapped with the NOAA Biogeography classification scheme. When the two systems are merged, it is likely that the shape of the polygons in those maps will not change, but the attribute codes will need to be updated for comparison with future maps.

\section{Concluding Remarks}

The assembly of experts from the NPS and other Federal and non-Federal agencies at this workshop clarified the needs and goals of the NPS SBMP. It is the first step in designing the benthic mapping program. The final success of the SBMP will be determined by available funding and the ability to leverage partnerships for mapping shared resources. Implementation of the NPS SBMP is essential to proper management and protection of submerged resources.

\section{Online Materials}

Workshop website:

http://www.nature.nps.gov/water/USGS/index.cfm

Workshop presentations:

http://www.nature.nps.gov/water/USGS/Workshop_Presentations.cfm

\section{References Cited}

Anderson, T.J., Cochrane, G.R., Roberts, D.A., Chezar, H., and Hatcher, G., 2007, A rapid method to characterize seabed habitats and associated macro-organisms, in Todd, B.J., and Greene, H.G., eds., Mapping the seafloor for habitat characterization: Geological Association of Canada, p. 71-79.

Andréfouët, S., Hochberg, E.J., Chevillon, C., Muller-Karger, F.E., Brock, J.C., and Hu, C., 2005, Multi-scale remote sensing of coral reefs, in Miller, R.L., Del Castillo, C.E., and McKee, B.A., eds., Remote sensing of coastal aquatic environments: Technologies, Techniques and Applications: Springer, p. 297-316. 
Casey, K.S., and Cornillon, P., 2001, Global and regional sea surface temperature trends: Journal of Climate, v. 14, no. 18, p. 3801-3818.

Cochrane, G.R., Golden, N.E., Dartnell, Pete, Schroeder, D.M., and Finlayson, D.P., 2007, Seafloor mapping and benthic habitat GIS for southern California, Volume III: U.S.

Geological Survey Open-File Report 2007-1271, available online at http://pubs.usgs.gov/of/2007/1271/.

Cochrane, G.R., Nasby, N.M., Reid, J.A., Waltenburger, Ben, and Lee, K.M., 2003, Nearshore benthic habitat GIS for the Channel Islands National Marine Sanctuary and southern California state fisheries reserves, Volume 1: U.S. Geological Survey Open-File Report 03-85, available online at: http://geopubs.wr.usgs.gov/open-file/of03-85/.

Collier, J.S., and Humber, S.R., 2007, Time-lapse side-scan sonar imaging of bleached coral reefs: A case study from the Seyhelles: Remote Sensing of Environment, v. 108, no. 4, p. 339356.

Cowardin, L.M., Carter, V., Golet, F.C., and LaRoe, E.T., 1979, Classification of wetlands and deepwater habitats of the United States: U.S. Fish and Wildlife Service FWS/OBS-79/31, $103 \mathrm{p}$.

Done, T., and Jones, R., 2006, Tropical coastal ecosystems and climate change prediction: Global and local risks, in Phinney, J.T., Hoegh-Guldberg, O., Kleypas, J., Skirving, W., and Strong, A.E., eds., Coral reefs and climate change: Science and Management: Washington, D.C., American Geophysical Union, p. 5-32.

Gibbs, A.E., Cochran, S.A., Logan, J.B., and Grossman, E.E., 2007, Benthic habitats and offshore geological resources of Kaloko-Honokohau National Historical Park, Hawai i: U.S. Geological Survey Scientific Investigations Report 2006-5256, p. 62.

Greene, H.G., Bizzarro, J.J., O’Connell, V.M., and Brylinsky, C.K., 2007, Construction of digital potential marine benthic habitat maps using a coded classification scheme and its applications, in Todd, B.J., and Greene, H.G., eds., Mapping the seafloor for habitat characterization: Geological Association of Canada, p. 145-159.

Greene, H.G., Wakefield, W.W., Sullivan, D.E., McRea, J.E., Jr., Cailliet, G.M., Yoklavich, M.M., Starr, R.M., and O'Connell, V.M., 1999, A classification scheme for deep seafloor habitats: Oceanologica Acta, v. 22, no. 6, p. 663-678.

Hooper, D.U., Chapin, F.S., Ewel, J.J., Hector, A., Inchausti, P., Lavorel, S., Lawton, J.H., Lodge, D.M., Loreau, M., Naeem, S., Schmid, B., Setala, H., Symstad, A.J., Vandermeer, J., and Wardle, D.A., 2005, Effects of biodiversity on ecosystem functioning: A consensus of current knowledge: Ecological Monographs, v. 75, no. 1, p. 3-35.

Hu, C., Muller-Karger, F.E., Vargo, G.A., Neely, M.B., and Johns, E., 2004, Linkages between coastal runoff and the Florida Keys ecosystem: A study of a dark plume event: Geophysical Research Letters, v. 31, no. 15, p. L15307, doi: 15310.11029/12004GL020382.

Jennings, M.D., Faber-Langendoem, D., Loucks, O.L., Peet, R.K., and Roberts, D., 2009, Characterizing associations and alliances of the U.S. National Vegetation Classification: Ecological Monographs, v.79, no. 2, p. 173-199.

Jokiel, P.L., and Brown, E.K., 2004, Global warming, regional trends and inshore environmental conditions influence coral bleaching in Hawaii: Global Change Biology, v. 10, no. 10, p. 1627 1641.

LaPointe, B.E., 1997, Nutrient thresholds for bottom-up control of macroalgal blooms on coral reefs in Jamaica and southeast Florida: Limnology and Oceanography, v. 42, p. 1119-1131. 
Lidz, B.H., Brock, J.C., and Nagle, D.B., 2008, Utility of shallow-water ATRIS images in defining biogeologic processes and self-similarity in skeletal Scleractinia, Florida reefs: Journal of Coastal Research, v. 24, no. 5, p. 1320-1338.

Lundblad, E.R., Wright, D.J., Miller, J., Larkin, E.M., Rinehart, R., Naar, D.F., Donahue, B.T., Anderson, S.M., and Battista, T., 2006, A benthic terrain classification scheme for American Samoa: Marine Geodesy, v. 29, no. 2, p. 89-111.

Madden, C.J., Goodin, K., Allee, B., Finkbeiner, M., and Bamford, D., 2008, Coastal and marine ecological classification standard, Version III: NOAA and NatureServe, $77 \mathrm{p}$.

Madden, C.J., Grossman, D.H., and Goodin, K.L., 2005, Coastal and marine systems of North America: Framework for an ecological classification standard, Version II: NOAA and NatureServe, $40 \mathrm{p}$.

Moses, C.S., Nayegandhi, A., Brock, J., and Beavers, R., in press, A servicewide benthic mapping program for National Parks: U.S. Geological Survey Open-File Report 201X-xxxx, $93 \mathrm{p}$.

National Park Service, Natural resource inventory and monitoring guidelines (NPS 75), p. 40, http://www.nature.nps.gov/nps75/nps75.pdf.

National Park Service, Natural resources management reference manual \#77, http://www.nature.nps.gov/rm77/.

Nelson, K., and Beavers, R., 2002, Coastal geology mapping protocols for the Atlantic and Gulf National Park units: National Park Service NPS-D-2269, 48 p.

NOAA-CRCP, 2008, A classification scheme for mapping the shallow-water coral ecosystems of southern Florida: NOAA Coral Reef Conservation Program, P.14, available online at http://ccma.nos.noaa.gov/ecosystems/coralreef/FLClassScheme.pdf.

Poppe, L.J., Paskevich, V.F., Butman, B., Ackerman, S.D., Danforth, W.W., Foster, D.S., and Blackwood, D.S., 2005, Geological interpretation of bathymetric and backscatter imagery of the sea floor off eastern Cape Cod, Massachusetts: U.S. Geological Survey Open-File Report 2005-1048, available online at: http://woodshole.er.usgs.gov/pubs/of2005-1048/index.htm.

Quintal, R.T., Dysart, P., and Greene, R., 2007, Automated side-scan data analysis: A system for target detection, classification and measurement: Hydro International, v. 11, no. 9, p. 22-25.

Zawada, D.G., Thompson, P.R., and Butcher, J., 2008, A new towed platform for the unobtrusive surveying of benthic habitats and organisms: Revista de Biologia Tropical, v. 56, no. 1, p. 5163. 


\section{Appendix 1. Workshop Participants}

\begin{tabular}{|c|c|c|c|c|c|}
\hline Last name & First name & Affiliation & Title & Phone & E-mail \\
\hline Allee & Becky & NOAA-CSC & Sr. Scientist & $228-688-1701$ & becky.allee@noaa.gov \\
\hline Barnhardt & Walter & USGS & Geologist & $508-457-2355$ & wbarnhardt@usgs.gov \\
\hline Battista & Tim & NOAA & Oceanographer & $301-713-3028$ & tim.battista@noaa.gov \\
\hline Beavers & Rebecca & NPS-GRD & $\begin{array}{l}\text { Coastal } \\
\text { Geologist }\end{array}$ & $303-987-6945$ & rebecca_beavers@nps.gov \\
\hline Borrelli & Mark & $\begin{array}{l}\text { Texas A\&M } \\
\text { University }\end{array}$ & $\begin{array}{l}\text { Coastal } \\
\text { Geologist }\end{array}$ & $303-969-2171$ & mark_borrelli@partner.nps.gov \\
\hline Brock & John & USGS-CMGP & Geologist & $727-637-1245$ & jbrock@usgs.gov \\
\hline Brouwers & Elisabeth & USGS & $\begin{array}{l}\text { Regional Chief } \\
\text { Biologist }\end{array}$ & $303-236-2730$ & brouwers@usgs.gov \\
\hline Brown & Karl & NPS-NRPC & Biologist & $970-225-3591$ & karl_brown@nps.gov \\
\hline Brunner & Julia & NPS & $\begin{array}{l}\text { Regulatory } \\
\text { Specialist }\end{array}$ & $303-969-2012$ & julia_f_brunner@nps.gov \\
\hline Budde & Peter & NPS-NRPC & NR GIS Prog & $970-225-3559$ & peter_budde@nps.gov \\
\hline Bunn & James & $\begin{array}{l}\text { NOAA- } \\
\text { NGDC }\end{array}$ & NOAA Corps & $303-497-6429$ & james.a.bunn@noaa.gov \\
\hline Cochran & Susan & USGS & Geologist & $831-427-4745$ & scochran@usgs.gov \\
\hline Cochrane & Guy & USGS & Geophysicist & $831-427-4754$ & gcochrane@usgs.gov \\
\hline Connors & Tom & NPS-GRD & Geologist & $303-969-2093$ & tim_connors@nps.gov \\
\hline Cross & Jeff & NPS-OCRB & OCRB Chief & $970-225-3547$ & jeffrey_cross@nps.gov \\
\hline Dickison & George & NPS-NRPC & Center Director & $970-225-3557$ & george_dickison@nps.gov \\
\hline Flocks & $\mathrm{Jim}$ & USGS & Geologist & $727-803-8747$ & jflocks@usgs.gov \\
\hline Flood & Roger & $\begin{array}{l}\text { Stony Brook } \\
\text { Univ. }\end{array}$ & Professor & $631-632-6971$ & roger.flood@sunysb.edu \\
\hline Gafvert & Ulf & NPS & GIS Specialist & $715-682-0632$ & ulg_gafvert@nps.gov \\
\hline Gende & Scott & NPS & $\begin{array}{l}\text { Coastal } \\
\text { Ecologist }\end{array}$ & $907-364-2622$ & scott_gende@nps.gov \\
\hline Greene & Gary & $\begin{array}{l}\text { Moss Landing } \\
\text { Marine Lab }\end{array}$ & $\begin{array}{l}\text { Professor- } \\
\text { Geologist }\end{array}$ & $360-376-4993$ & greene@mlml.calstate.edu \\
\hline Hamer & Tammy & NPS-CSU & Research Assoc & $970-267-7201$ & tammy_hamer@partner.nps.gov \\
\hline
\end{tabular}




\begin{tabular}{|c|c|c|c|c|c|}
\hline Last name & First name & Affiliation & Title & Phone & E-mail \\
\hline Heise & Bruce & NPS-GRD & Geologist & $303-969-2017$ & bruce_heise@nps.gov \\
\hline Jackson & Bill & NPS-WRD & Hydrologist & $970-225-3503$ & bill_jackson@nps.gov \\
\hline Johnson & Roger & NPS-LRD & $\begin{array}{l}\text { Chief } \\
\text { Cartographer }\end{array}$ & $970-484-6428$ & roger.m.johnson@nps.gov \\
\hline Johnson & Sam & USGS-CMG & Chief Scientist & $831-427-4746$ & sjohnson@usgs.gov \\
\hline Klipp & Emily & Jacobs-USGS & Admin Asst & $727-803-8747$ & eklipp@usgs.gov \\
\hline Kopp & Blaine & USGS & Oceanographer & $207-622-8201$ & bkopp@usgs.gov \\
\hline Latham & Penny & NPS & $\begin{array}{l}\text { PWR I\&M } \\
\text { Regional Coord }\end{array}$ & $206-220-4267$ & penny_latham@nps.gov \\
\hline Lea & Chris & NPS-BRMD & Botanist & $303-969-2807$ & chris_lea@nps.gov \\
\hline McCoy & Carol & NPS-GRD & PEPB Chief & $303-969-2096$ & carol_mccoy@nps.gov \\
\hline McLean & Sue & $\begin{array}{l}\text { NOAA- } \\
\text { NGDC }\end{array}$ & $\begin{array}{l}\text { Chief Marine } \\
\text { Division }\end{array}$ & $303-497-6478$ & Susan.mclean@noaa.gov \\
\hline Moses & Chris & Jacobs-USGS & Benthic Scientist & $727-803-8747$ & cmoses@usgs.gov \\
\hline Murphy & Larry & NPS-SRC & $\begin{array}{l}\text { Chief } \\
\text { Archaeologist }\end{array}$ & $505-988-6790$ & larry_murphy@nps.gov \\
\hline Nayegandhi & Amar & Jacobs-USGS & $\begin{array}{l}\text { Computer } \\
\text { Scientist }\end{array}$ & $727-803-8747$ & anayegandhi@usgs.gov \\
\hline Pierce & Robert & DOI & Chief EGIM & 202-208-4939 & rrpierce@usgs.gov \\
\hline Rafferty & Patti & NPS & $\begin{array}{l}\text { Coastal } \\
\text { Ecologist }\end{array}$ & $631-687-4767$ & patricia_rafferty@nps.gov \\
\hline Roman & Charles & NPS & $\begin{array}{l}\text { Coastal } \\
\text { Ecologist }\end{array}$ & $401-874-6886$ & charles_roman@nps.gov \\
\hline Ruttenberg & Ben & NPS & $\begin{array}{l}\text { Marine } \\
\text { Ecologist }\end{array}$ & $305-252-0347$ & ben_ruttenberg@nps.gov \\
\hline Schupp & Courtney & NPS-ASIS & $\begin{array}{l}\text { Coastal } \\
\text { Geologist }\end{array}$ & $410-614-1443$ & courtney_schupp@nps.gov \\
\hline Smith & Tim & NPS-RIMD & $\begin{array}{l}\text { GPS Program } \\
\text { Coord }\end{array}$ & $303-969-2086$ & tim_smith@nps.gov \\
\hline Taylor & Christine & NOAA-NMS & Geographer & $301-713-7277$ & christine.taylor@noaa.gov \\
\hline West & Larry & NPS & $\begin{array}{l}\text { Regional Coord } \\
\text { I\&M }\end{array}$ & $404-562-3113$ & larry_west@nps.gov \\
\hline Williams & Gary & NPS-NRPC & OIME Chief & $970-225-3539$ & gary_williams@nps.gov \\
\hline York & Linda & NPS & $\begin{array}{l}\text { Coastal } \\
\text { Geologist }\end{array}$ & $404-562-3113$ & linda_york@nps.gov \\
\hline Zawada & Dave & USGS & $\begin{array}{l}\text { Research } \\
\text { Oceanographer }\end{array}$ & 727-803-8747 & dzawada@usgs.gov \\
\hline
\end{tabular}




\section{Appendix 2. Workshop Agenda}

Moderator: Elisabeth Brouwers, Bureau Approving Official, Central Region Geology, USGS

Tuesday, June 3, 2008

Introductions

8:00 Coffee and muffins

8:30 Chris Moses $\quad$ Welcome, introductions, and workshop goals

Session 1: NPS Benthic Habitat Mapping Status and Needs

8:40 George Dickison Who are we doing all this for, really?

8:50 Bill Jackson $\quad$ Scope of NPS benthic habitat resources

9:00 Julia Brunner NPS ocean and coastal mapping efforts - overview and direction

9:20 Charles Roman \& Benthic marine habitat mapping in the Northeast

Courtney Schupp Region: Accomplishments, future needs, and management applications

9:40 Larry West $\quad$ Southeastern Region benthic mapping status/needs

10:00 Coffee Break

10:10 Ulf Gafvert $\quad$ Midwest Region benthic mapping status/needs

10:30 Penny Latham PWR: Preliminary status of benthic habitat mapping and benthic habitat classification

10:50 Scott Gende $\quad$ Alaska Region benthic mapping status/needs 


12:30 Lunch

\section{Session 2: Prior and Existing NPS Mapping Programs}

1:40 Roger Johnson Enterprise mapping and data management within the National Park Service

2:00 Karl Brown NPS vegetation mapping - Suggestions to be applied to benthic habitat mapping

2:30 Bruce Heise In over our heads - A terrestrial geologist's observations on coastal and marine mapping

2:50 Larry Murphy Mapping submerged cultural resources in the NPS Integration into the benthic habitat mapping program

\section{3:10 Coffee Break}

Session 3: Benthic Habitat Mapping Capabilities

3:20 $\quad$ Amar Nayegandhi $\quad$ Status of USGS Lidar projects in NPS areas

3:40 Walter Barnhardt USGS seafloor-mapping activities in the Northeast Region $(N Y, M A)$

4:00 Guy Cochrane Mapping seafloor substrate for benthic habitat studies in temperate waters

4:20 Chris Moses $\quad$ Multispectral satellite and aerial imagery in NPS areas

4:50 Dave Zawada Along-Track Reef-Imaging System (ATRIS): Not just for reefs

5:10 Discussion

5:30 Adjourn Day 1 
Wednesday, June 4, 2008

$7: 45$

Coffee and muffins

Session 4: USGS \& NOAA Mapping Programs, Classification Schemes, and Geospatial Data Networks

8:00 Christine Taylor Status of seafloor mapping and classification within the National Marine Sanctuaries

8:20 Tim Battista NOAA mapping approach for tropical marine environments

8:40 Becky Allee Developing a national standard for classification of coastal and marine habitats

9:10 Gary Greene $\quad$ A classification scheme for deep seafloor habitats

9:30 Sue McLean Collect once, use often-Mining the nation's marine archives to support habitat characterization

9:50 Robert Pierce Geospatial One Stop - What's in it for the NPS?

10:10 Coffee Break

10:20 TBA Discussion of classification schemes: Advantages and disadvantages

11:00 Lunch and Field Trip (TBA)

Session 5: Break-outs

1:30 Chris Moses $\quad$ Session objectives and charge

1:40 Small group Break-out Task 1-Recommendation for classification schemes in tropical regions

1:40 Small group Break-out Task 2 -Recommendation for classification schemes in temperate regions 
1:40 Small group (cont'd)

Small group

4:50 Wrap-up

5:00 Adjourn Day 2
Break-out Task 3 -Recommendation for classification schemes in high-latitude regions

Break-out Task 4-Recommendation for classification schemes in lakes and rivers

Thursday, June 5, 2008

Session 6: Moving Forward - Recommendations for Classification Schemes

\begin{tabular}{|c|c|c|}
\hline \multicolumn{3}{|c|}{ Coffee and muffins } \\
\hline $8: 30$ & Chris Moses & Session objectives and charge \\
\hline $8: 40$ & Karl Brown & Administrative needs for a servicewide program \\
\hline 9:00 & Group Leaders & Break-out reports \\
\hline 10:15 & Coffee Break & \\
\hline 10:30 & Group Leaders & Break-out reports (cont'd) \\
\hline 11:30 & $\begin{array}{l}\text { Discussion and } \\
\text { wrap-up }\end{array}$ & \\
\hline $12: 30$ & Meeting adjour & \\
\hline
\end{tabular}




\section{Appendix 3. Ocean and Great Lakes Parks with Submerged Acreage}

[See figure 3-1. $\mathrm{km}^{2}$; square kilometer, $\mathrm{km}$, kilometer; m, meter]

\begin{tabular}{|c|c|c|c|c|c|c|c|}
\hline & Park name & $\begin{array}{l}\text { NPS } \\
\text { region }\end{array}$ & State & $\begin{array}{l}\text { Water } \\
\text { (acres) }\end{array}$ & $\begin{array}{l}\text { Water } \\
\left(\mathrm{km}^{2}\right)\end{array}$ & $\begin{array}{l}\text { Coastline } \\
(\mathrm{km})\end{array}$ & $\begin{array}{l}\text { Depth } \\
\text { (m) }\end{array}$ \\
\hline 1 & Acadia National Park & $\mathrm{NE}$ & ME & 11,900 & 48 & 83 & \\
\hline 2 & American Memorial Park & PW & CNMI & 0 & 0 & 5 & \\
\hline 3 & $\begin{array}{l}\text { Aniakchak National Monument \& } \\
\text { Preserve }\end{array}$ & AK & $\mathrm{AK}$ & 0 & 0 & 112 & \\
\hline 4 & Apostle Islands National Lakeshore & MW & WI & 27,232 & 110 & 246 & \\
\hline 5 & Assateague Island National Seashore & $\mathrm{NE}$ & MD-VA & 31,411 & 127 & 138 & \\
\hline 6 & Bering Land Bridge National Preserve & $\mathrm{AK}$ & $\mathrm{AK}$ & & & 280 & \\
\hline 7 & Biscayne National Park & SE & FL & 168,666 & 683 & 80 & 18 \\
\hline 8 & $\begin{array}{l}\text { Boston Harbor Islands National } \\
\text { Recreation Area }\end{array}$ & $\mathrm{NE}$ & MA & 0 & 0 & & \\
\hline 9 & Buck Island Reef National Monument & SE & VI & 18,839 & 76 & 5 & 1,703 \\
\hline 10 & Cabrillo National Monument & PW & $\mathrm{CA}$ & 125 & 1 & 2 & 10 \\
\hline 11 & Canaveral National Seashore & SE & FL & 39,680 & 161 & 38 & \\
\hline 12 & Cape Cod National Seashore & $\mathrm{NE}$ & MA & 16,523 & 67 & 80 & \\
\hline 13 & Cape Hatteras National Seashore & SE & $\mathrm{NC}$ & 3,993 & 16 & 245 & \\
\hline 14 & $\begin{array}{l}\text { Cape Kruesenstern National } \\
\text { Monument }\end{array}$ & $\mathrm{AK}$ & $\mathrm{AK}$ & 0 & 0 & 189 & \\
\hline 15 & Cape Lookout National Seashore & SE & $\mathrm{NC}$ & 19,674 & 80 & 90 & \\
\hline 16 & $\begin{array}{l}\text { Castillo de San Marcos National } \\
\text { Monument }\end{array}$ & SE & FL & 0 & 0 & 2 & \\
\hline 17 & Channel Islands National Park & PW & $\mathrm{CA}$ & 124,299 & 503 & 282 & 387 \\
\hline 18 & Christiansted National Historic Site & SE & VI & 0 & 0 & 2 & \\
\hline 19 & Colonial National Historical Park & $\mathrm{NE}$ & VA & & & 48 & \\
\hline 20 & Cumberland Island National Seashore & SE & GA & 10,262 & 42 & 48 & \\
\hline 21 & De Soto National Memorial & SE & FL & 0 & 0 & 2 & \\
\hline
\end{tabular}




\begin{tabular}{|c|c|c|c|c|c|c|c|}
\hline & Park name & $\begin{array}{l}\text { NPS } \\
\text { region }\end{array}$ & State & $\begin{array}{l}\text { Water } \\
\text { (acres) }\end{array}$ & $\begin{array}{l}\text { Water } \\
\left(\mathrm{km}^{2}\right)\end{array}$ & $\begin{array}{l}\text { Coastline } \\
(\mathrm{km})\end{array}$ & $\begin{array}{l}\text { Depth } \\
\text { (m) }\end{array}$ \\
\hline 22 & Dry Tortugas National Park & SE & FL & 64,661 & 262 & 6 & 33 \\
\hline 23 & $\begin{array}{l}\text { Ebey's Landing National Historical } \\
\text { Reserve }\end{array}$ & PW & WA & & & 2 & \\
\hline 24 & Everglades National Park & SE & FL & 625,000 & 2,530 & 248 & 8 \\
\hline 25 & Fire Island National Seashore & $\mathrm{NE}$ & NY & 4,411 & 18 & 83 & \\
\hline 26 & Fort Caroline National Memorial & SE & FL & 0 & 0 & 0 & \\
\hline 27 & Fort Clatsop National Memorial & PW & OR & 0 & 0 & 2 & \\
\hline 28 & Fort Frederica National Monument & SE & GA & 0 & 0 & 2 & \\
\hline 29 & Fort Matanzas National Monument & SE & FL & 0 & 0 & 2 & \\
\hline 30 & $\begin{array}{l}\text { Fort McHenry National Monument } \\
\text { and Historic Shrine }\end{array}$ & $\mathrm{NE}$ & MD & 0 & 0 & 2 & \\
\hline 31 & Fort Point National Historic Site & PW & $\mathrm{CA}$ & 0 & 0 & 2 & \\
\hline 32 & Fort Pulaski National Monument & SE & GA & & & & \\
\hline 33 & Fort Raleigh National Historic Site & SE & $\mathrm{NC}$ & 0 & 0 & 2 & \\
\hline 34 & Fort Sumter National Monument & SE & $\mathrm{SC}$ & 125 & 1 & 2 & \\
\hline 35 & Gateway National Recreation Area & $\mathrm{NE}$ & NY & 17,989 & 73 & & \\
\hline 36 & $\begin{array}{l}\text { Glacier Bay National Park and } \\
\text { Preserve }\end{array}$ & $\mathrm{AK}$ & $\mathrm{AK}$ & 601,600 & 2,436 & 1,896 & \\
\hline 37 & $\begin{array}{l}\text { Golden Gate National Recreational } \\
\text { Area }\end{array}$ & PW & $\mathrm{CA}$ & 3,657 & 15 & 45 & \\
\hline 38 & Grand Portage National Monument & MW & MN & 0 & 0 & 2 & \\
\hline 39 & Gulf Islands National Seashore & SE & $\begin{array}{c}\text { FL \& } \\
\text { MS }\end{array}$ & 115,189 & 466 & 122 & \\
\hline 40 & Haleakala National Park & PW & HI & 0 & 0 & 2 & \\
\hline 41 & Hawaii Volcanoes National Park & PW & HI & 0 & 0 & 69 & \\
\hline 42 & Indiana Dunes National Lakeshore & MW & IN & 436 & 2 & 40 & \\
\hline 43 & Isle Royale National Park & MW & MI & 438,009 & 1,773 & 541 & \\
\hline 44 & $\begin{array}{l}\text { Jean Lafitte National Historical Park } \\
\text { and Preserve }\end{array}$ & SE & LA & 156 & 1 & 29 & \\
\hline
\end{tabular}




\begin{tabular}{|c|c|c|c|c|c|c|c|}
\hline & Park name & $\begin{array}{l}\text { NPS } \\
\text { region }\end{array}$ & State & $\begin{array}{l}\text { Water } \\
\text { (acres) }\end{array}$ & $\begin{array}{l}\text { Water } \\
\left(\mathrm{km}^{2}\right)\end{array}$ & $\begin{array}{l}\text { Coastline } \\
(\mathrm{km})\end{array}$ & $\begin{array}{l}\text { Depth } \\
\text { (m) }\end{array}$ \\
\hline 45 & Kalaupapa National Historical Park & PW & HI & 2,000 & 8 & 2 & \\
\hline 46 & $\begin{array}{l}\text { Kaloko-Honokohau National } \\
\text { Historical Park }\end{array}$ & PW & $\mathrm{HI}$ & 597 & 2 & 3 & \\
\hline 47 & Katmai National Park \& Preserve & $\mathrm{AK}$ & $\mathrm{AK}$ & 672,000 & 2,721 & 795 & \\
\hline 48 & Kenai Fjords National Park & $\mathrm{AK}$ & $\mathrm{AK}$ & 0 & 0 & 749 & \\
\hline 49 & $\begin{array}{l}\text { Klondike Gold Rush National } \\
\text { Historical Park }\end{array}$ & $\mathrm{AK}$ & AK & 0 & 0 & 2 & \\
\hline 50 & Lake Clark National Park \& Preserve & $\mathrm{AK}$ & $\mathrm{AK}$ & 0 & 0 & 203 & \\
\hline 51 & National Park of American Samoa & PW & AS & 3,200 & 13 & 53 & \\
\hline 52 & $\begin{array}{l}\text { New Bedford Whaling National } \\
\text { Historical Park }\end{array}$ & $\mathrm{NE}$ & MA & 0 & 0 & 0 & \\
\hline 53 & Olympic National Park & PW & WA & 15,186 & 61 & 91 & \\
\hline 54 & Padre Island National Seashore & $\mathrm{IM}$ & $\mathrm{TX}$ & 32,500 & 132 & 106 & \\
\hline 55 & $\begin{array}{l}\text { Perry's Victory and International } \\
\text { Peace Memorial }\end{array}$ & MW & $\mathrm{OH}$ & 0 & 0 & 2 & \\
\hline 56 & Pictured Rocks National Lakeshore & MW & MI & 9,770 & 40 & 75 & \\
\hline 57 & Point Reyes National Seashore & PW & $\mathrm{CA}$ & 22,000 & 89 & 288 & \\
\hline 58 & $\begin{array}{l}\text { Port Chicago Naval Magazine } \\
\text { National Memorial }\end{array}$ & PW & $\mathrm{CA}$ & 0 & 0 & 2 & \\
\hline 59 & $\begin{array}{l}\text { Pu'uhonua o Honaunau National } \\
\text { Historical Park }\end{array}$ & PW & $\mathrm{HI}$ & 0 & 0 & 2 & \\
\hline 60 & $\begin{array}{l}\text { Puukohola Heiau National Historic } \\
\text { Site }\end{array}$ & PW & $\mathrm{HI}$ & 4 & 0 & 2 & \\
\hline 61 & Redwood National and State Park & PW & $\mathrm{CA}$ & 5,939 & 24 & 58 & \\
\hline 62 & Salem Maritime National Historic Site & NE & MA & 0 & 0 & 0 & \\
\hline 63 & $\begin{array}{l}\text { Salt River Bay National Historical } \\
\text { Park and Ecological Preserve }\end{array}$ & SE & VI & 600 & 2 & 2 & \\
\hline 64 & $\begin{array}{l}\text { San Francisco Maritime National } \\
\text { Historical Park }\end{array}$ & PW & $\mathrm{CA}$ & 0 & 0 & 2 & \\
\hline 65 & $\begin{array}{l}\text { San Juan Island National Historical } \\
\text { Park }\end{array}$ & PW & WA & 0 & 0 & 2 & \\
\hline 66 & $\begin{array}{l}\text { Santa Monica Mountains National } \\
\text { Recreation Area }\end{array}$ & PW & $\mathrm{CA}$ & 0 & 0 & 66 & \\
\hline 67 & Sitka National Historical Park & $\mathrm{AK}$ & $\mathrm{AK}$ & 50 & 0 & 2 & \\
\hline
\end{tabular}




\begin{tabular}{|c|c|c|c|c|c|c|c|}
\hline & Park name & $\begin{array}{l}\text { NPS } \\
\text { region }\end{array}$ & State & $\begin{array}{l}\text { Water } \\
\text { (acres) }\end{array}$ & $\begin{array}{l}\text { Water } \\
\left(\mathrm{km}^{2}\right)\end{array}$ & $\begin{array}{l}\text { Coastline } \\
(\mathrm{km})\end{array}$ & $\begin{array}{l}\text { Depth } \\
\text { (m) }\end{array}$ \\
\hline 68 & $\begin{array}{l}\text { Sleeping Bear Dunes National } \\
\text { Lakeshore }\end{array}$ & MW & MI & 10,400 & 42 & 75 & \\
\hline 69 & $\begin{array}{l}\text { Timucuan Ecological and Historic } \\
\text { Preserve }\end{array}$ & SE & FL & 38,000 & 154 & 2 & \\
\hline 70 & USS Arizona Memorial & PW & HI & 0 & 0 & 2 & \\
\hline 71 & $\begin{array}{l}\text { Virgin Islands Coral Reef National } \\
\text { Monument }\end{array}$ & SE & VI & 13,893 & 56 & 5 & \\
\hline 72 & Virgin Islands National Park & SE & VI & 5,650 & 23 & 35 & 25 \\
\hline 73 & $\begin{array}{l}\text { War in the Pacific National Historical } \\
\text { Park }\end{array}$ & PW & GU & 1,000 & 4 & 6 & \\
\hline 74 & $\begin{array}{l}\text { Wrangell-St. Elias National Park \& } \\
\text { Preserve }\end{array}$ & $\mathrm{AK}$ & $\mathrm{AK}$ & 0 & 0 & 206 & \\
\hline
\end{tabular}




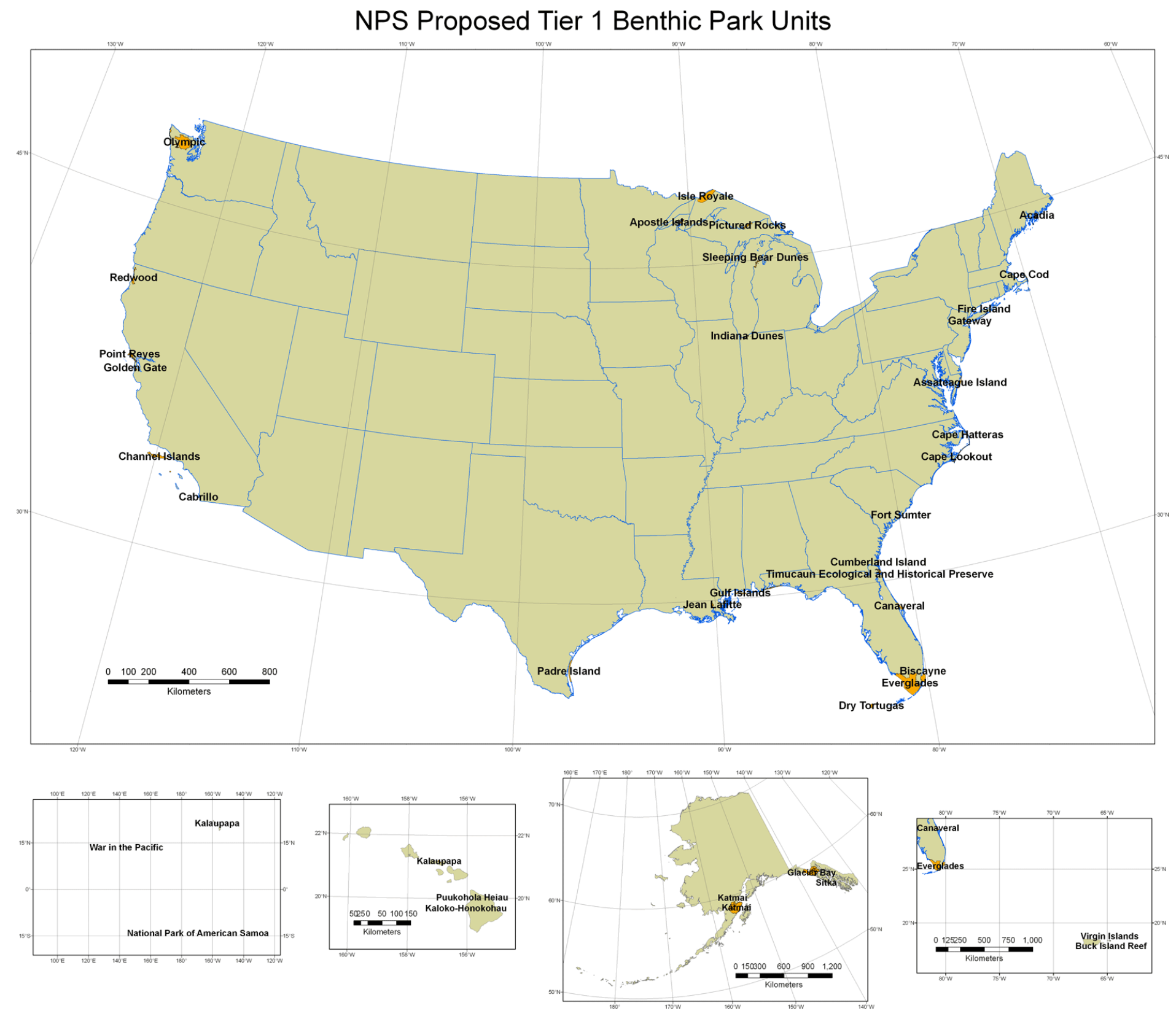

Figure 3-1. Location of ocean and Great Lake park units. 